Henrique Silva Bombana

Análise de anfetamina, cocaína e tetrahidrocanabinol em fluido oral de motoristas de caminhão que trafegam em rodovias do estado de São Paulo

Dissertação apresentada à Faculdade de Medicina da Universidade de São Paulo, para obtenção do título de Mestre em Ciências

Programa: Fisiopatologia Experimental Orientadora: Prof $^{a}$ Dr $^{\mathrm{a}}$ Vilma Leyton

São Paulo 
Henrique Silva Bombana

\title{
Análise de anfetamina, cocaína e tetrahidrocanabinol em fluido oral de motoristas de caminhão que trafegam em rodovias do estado de São Paulo
}

\author{
Dissertação apresentada à Faculdade de Medicina \\ da Universidade de São Paulo, para obtenção do \\ título de Mestre em Ciências \\ Programa: Fisiopatologia Experimental \\ Orientadora: Prof ${ }^{\mathrm{a}} \mathrm{Dr}^{\mathrm{a}}$ Vilma Leyton
}

(Versão corrigida. Resolução CoPGr 6018, de 03 de outubro de 2011. A versão original está disponível na Biblioteca FMUSP)

\section{São Paulo}




\section{Dados Internacionais de Catalogação na Publicação (CIP)}

Preparada pela Biblioteca da

Faculdade de Medicina da Universidade de São Paulo

(Oreprodução autorizada pelo autor

\section{Bombana, Henrique Silva}

Análise de anfetamina, cocaína e tetrahidrocanabinol em fluido oral de motoristas de caminhão que trafegam em rodovias do estado de São Paulo / Henrique Silva Bombana. -- São Paulo, 2016.

Dissertação(mestrado)--Faculdade de Medicina da Universidade de São Paulo. Programa de Fisiopatologia Experimental.

Orientadora: Vilma Leyton.

Descritores: 1.Drogas ilicitas 2.Acidentes de trânsito 3.Cocaína 4.Anfetamina 5.Cannabis 6.Caminhões 7.Estradas

USP/FM/DBD-420/16 


\section{Dedicatória}

Dedico esse trabalho à minha mãe, Maria Alice, por todo amor e por tudo que me proporcionou para que conseguisse chegar até aqui. Sem você não teria conseguido. 


\section{Agradecimentos}

A minha orientadora $\operatorname{Prof}^{a}{ }^{-} r^{a}$ Vilma Leyton pela oportunidade de realização deste trabalho e por todos os ensinamentos passados;

A Policia Rodoviária Federal pela parceria que possibilitou a coleta das amostras de fluido oral;

A banca do exame de qualificação pelas sugestões que aprimoraram este trabalho;

Ao Marcelo por toda ajuda nas horas de desespero no laboratório;

A todos no NIPH pela confirmação das amostras, em especial ao Hallvard Gjerde, por todo ensinamento e atenção;

A todos no laboratório, Dani, JuTaki, JuMaga, Helena, Ana e aprimorandos por toda ajuda e companheirismo;

A Mariana Veras pela utilização do espectrofotômetro necessário nas análises de triagem;

A Carol, por toda paciência, companheirismo e força que me passou, te amo!

A todos que de alguma forma me ajudaram na realização e conclusão deste trabalho;

Ao Laboratório de Investigação Médica - LIM 40 do Hospital das Clínicas da Faculdade de Medicina, pelo apoio na realização desse trabalho;

A Fundação de Amparo à Pesquisa do Estado de São Paulo (FAPESP) pela concessão do auxílio №: 2014/01824-0. 


\section{Normalização adotada}

Esta dissertação está de acordo com as seguintes normas em vigor no momento desta publicação:

- Referências: adaptado de International Committee of Medical Journals Editors (Vancouver).

- Universidade de São Paulo. Faculdade de Medicina. Divisão de Biblioteca e Documentação. Guia de apresentação de dissertações, teses e monografias. Elaborado por Anneliese Carneiro da Cunha, Maria Julia de

A. L. Freddi, Maria F. Crestana, Marinalva de Souza Aragão, Suely Campos Cardoso, Valéria Vilhena. 3a ed. São Paulo: Divisão de Biblioteca e Documentação; 2011.

- Abreviaturas dos títulos dos periódicos de acordo com List of Journals Indexed in Index Medicus. 


\section{Sumário}

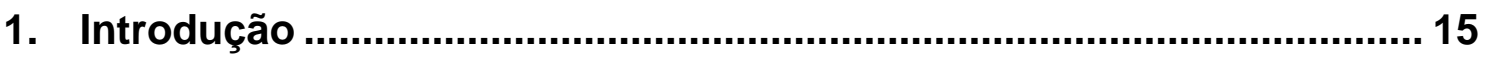

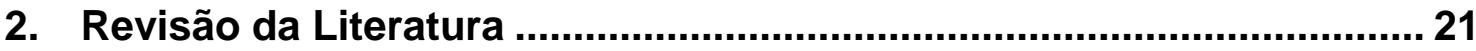

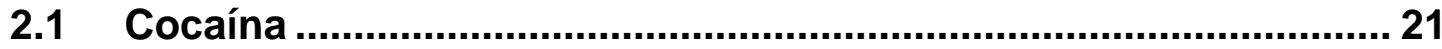

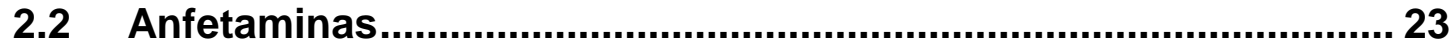

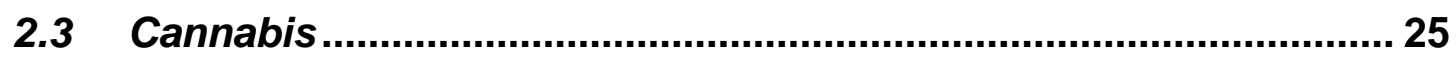

2.4 Drogas de abuso na direção veicular............................................ 27

2.4.1 Efeitos prejudiciais causados nos condutores ............................. 27

2.4.2 Prevalência do uso de drogas por condutores ............................ 28

2.5 Fluido oral na detecção de drogas de abuso ................................. 29

2.6 Uso de fluido oral para fiscalização no trânsito .............................. 33

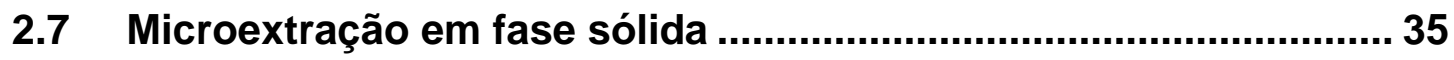

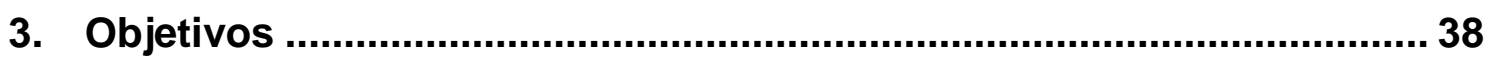

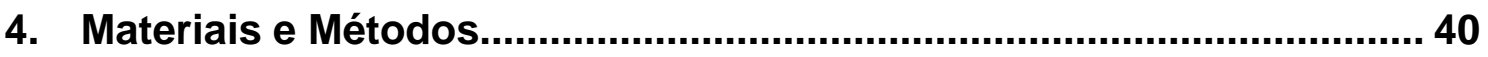

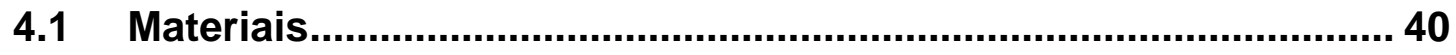

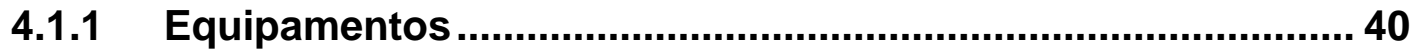

4.1.2 Reagentes e outros materiais................................................. 40

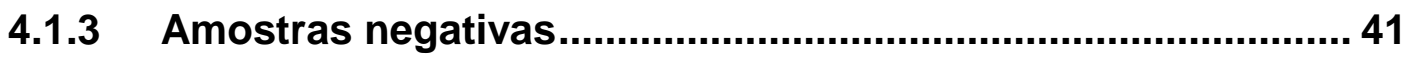

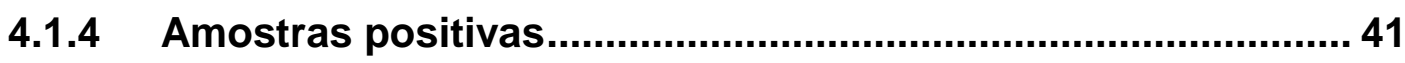

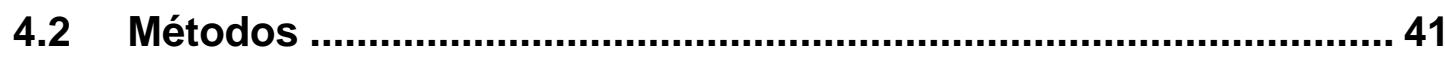

4.2.1 Comandos de Saúde nas Rodovias .......................................... 41

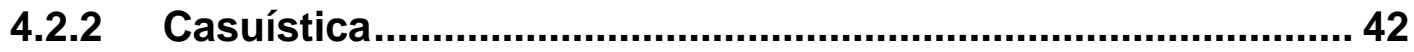

4.2.3 Abordagem dos motoristas ................................................... 43

4.2.4 Critério de inclusão e exclusão .................................................. 43

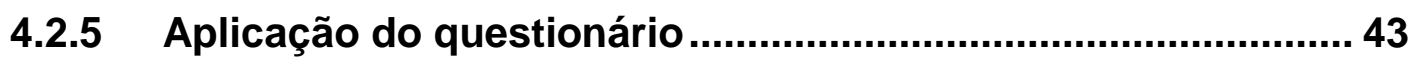

4.2.6 Coleta de amostras de fluido oral ........................................... 44

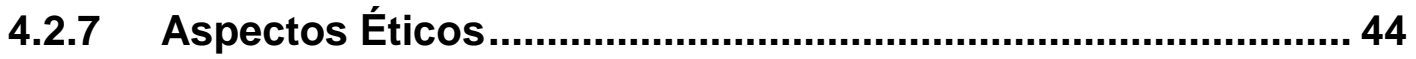

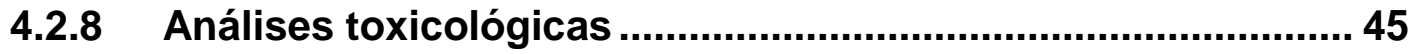

4.2.9 Validação dos métodos de confirmação .................................. 46

4.2.10 Análises estatísticas .............................................................. 52

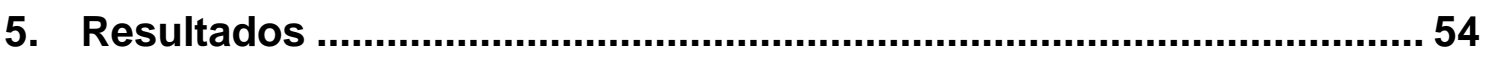




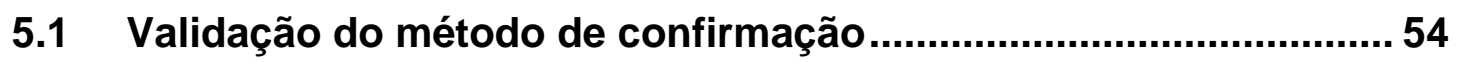

5.1.1 Limite de detecção e quantificação ....................................... 54

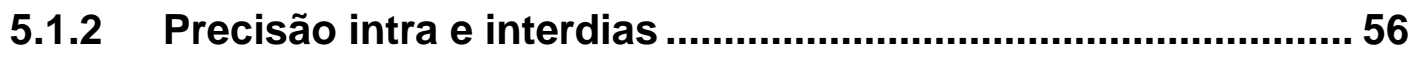

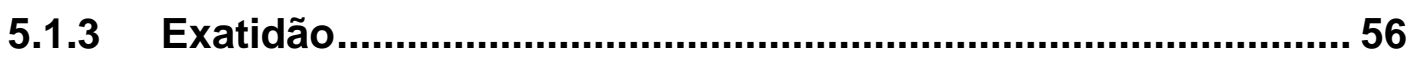

5.1.4 Linearidade e Heteroscedasticidade.................................... 57

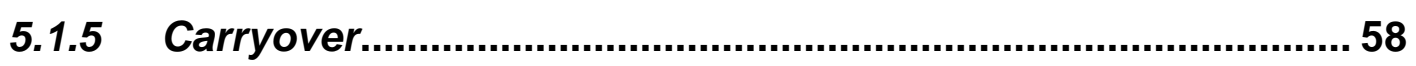

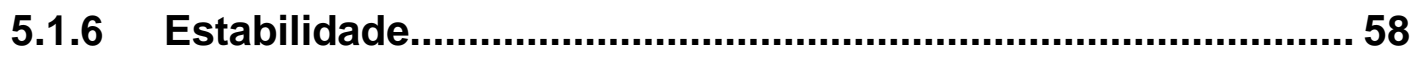

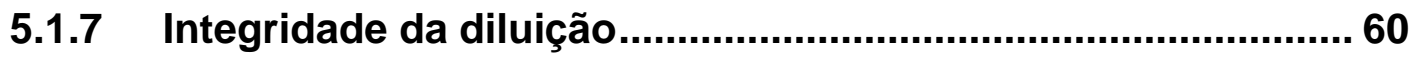

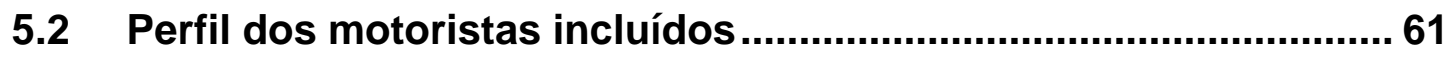

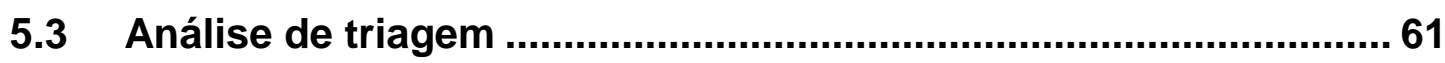

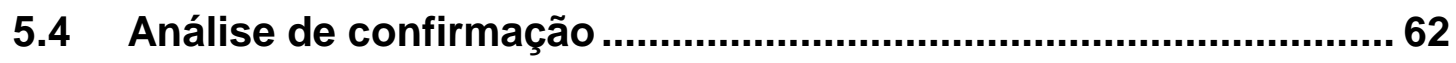

5.5 Perfil dos motoristas com amostras positivas ................................. 64

5.6 Comparação entre percurso e uso de substâncias psicoativas... 65

5.7 Probabilidade de envolvimento em acidentes de trânsito ............. 66

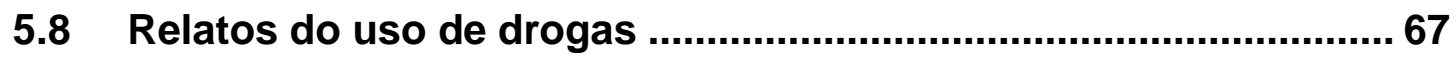

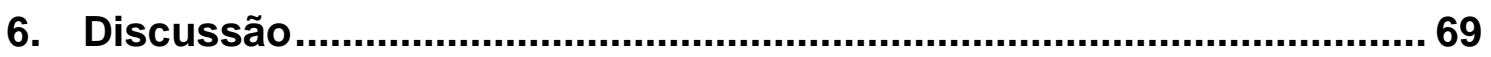

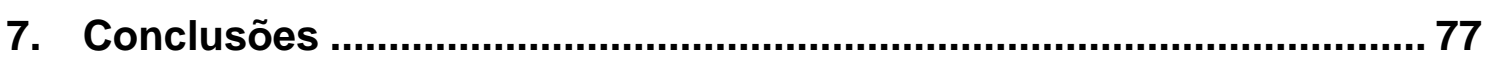

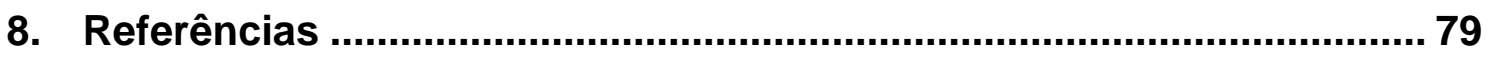




\section{Lista de abreviações}

ANVISA: Agência nacional de vigilância sanitária

AT: Acidentes de trânsito

GC-MS: Do inglês: Gas chromatography-mass spectrometry (Cromatografia gasosa acoplada à espectrometria de massas)

CQA: Controle de qualidade alto

CQB: Controle de qualidade baixo

CQM: Controle de qualidade médio

CSR: Comando de Saúde nas Rodovias

CV: Coeficiente de variação

DENATRAN: Departamento nacional de trânsito

ELISA: Do inglês: Enzyme-Linked Immunosorbent Assay (Ensaio de imunoabsorção enzimática)

LOB: Do inglês: Limit of blanc (Limite do branco)

LOD: Do inglês: Limit of detection (Limite de detecção)

LOQ: Do inglês: Limit of quantification (Limite de quantificação)

MDMA: 3,4-metilenodioximetanfetamina

MS: Ministério da Saúde

NIPH: Do inglês: Norwegian Institute of Public Health (Instituto Norueguês de Saúde Pública)

OMS: Organização Mundial da Saúde

ONU: Organização das Nações Unidas

PDMS: Polidimetilsiloxano

PRF: Polícia Rodoviária Federal

SIM: Do inglês: Select ion monitoring (Monitoramento selecionado de íons)

SENAD: Secretaria Nacional de Políticas sobre Drogas

SNC: Sistema Nervoso Central

SPME: Do inglês: Solid-phase microextraction (Microextração em fase sólida)

UPLC-MS/MS: Do inglês: Ultra Performance Liquid Chromatography - mass spectrometry in tandem (Cromatografia líquida de ultra performance acoplada à espectrometria de massas em sequência)

$\triangle$ 9-THC: Delta 9-Tetrahidrocanabinol 


\section{Lista de figuras}

Figura 1. Porcentagem de população, mortes por acidentes de trânsito e veículos registrados, separados de acordo com o perfil econômico dos países. Adaptado de OMS, 2015 16

Figura 2. Taxa de mortalidade por acidentes de trânsito a cada 100.000 habitantes, no Brasil, União Europeia, Estados Unidos da América e Noruega entre os anos de 1990 e 2010.

Figura 3. Estrutura química da molécula de cocaína....................................... 22

Figura 4. Estrutura química da molécula de anfetamina ............................... 24

Figura 5. Estrutura química da molécula do $\Delta 9$-Te trahidrocanabinol ( $\triangle 9-\mathrm{THC})$

Figura 6. Microextração em fase sólida por imersão direta da fibra ................ 36

Figura 7. Dispositivo de coleta de fluido oral, Quantisal ${ }^{\mathrm{TM}}$............................ 44

Figura 8. Cromatograma referente à amostra adicionada com $500 \mathrm{ng} / \mathrm{mL}$ de padrão de cocaína e cocaína-D3. ............................................................. 55

Figura 9. Cromatograma referente à amostra adicionada com $500 \mathrm{ng} / \mathrm{mL}$ de padrão de $\Delta$ 9-THC e $\Delta 9$-THC -D3......................................................... 55

Figura 10. Cromatograma referente à amostra adicionada com $500 \mathrm{ng} / \mathrm{mL}$ de padrão de anfetamina e anfetamina-D5 .................................................. 56

Figura 11. Número de identificações de cada uma das 5 substâncias encontradas nas amostras de fluido oral nas análises confirmatórias por UPLCMS/MS.

Figura 12. Comparação entre a média de percurso entre aqueles que relataram o uso e não de álcool e entre os motoristas que apresentaram resultados positivos e negativos para anfetamina, cocaína e $\triangle 9$-THC.

Figura 13. Distribuição da porcentagem de amostras positivas de acordo com percurso percorrido, estratificado em 3 níveis: de 0 a $500 \mathrm{Km}$, de 501 a $1500 \mathrm{Km}$ e de 1501 a $4500 \mathrm{Km}$. 66 


\section{Lista de tabelas}

Tabela 1 - CV intradia e interdia e exatidão obtidos nas três concentrações estudadas para cocaína.

Tabela 2 - CV intradia e interdia e exatidão obtidos nas três concentrações estudadas para $\triangle 9-\mathrm{THC}$. 57

Tabela 3 - CV intradia e interdia e exatidão obtidos nas três concentrações estudadas para anfetamina. 57

Tabela 4 - Faixas de concentração, equação obtida, coeficiente de correlação (R2), estudo de heteroscedeasticidade e fator de ponderação utilizados na validação dos métodos de confirmação para cocaína, $\triangle 9$-THC e anfetamina. 58 Tabela 5 - Variação (\%) de cada concentração de cocaína, em cada ambiente de armazenamento. 59

Tabela 6 - Variação (\%) de cada concentração de $\Delta 9-T H C$, em cada ambiente de armazenamento durante três dias consecutivos. 59

Tabela 7 - Variação (\%) de cada concentração de anfetamina, em cada ambiente de armazenamento durante três dias consecutivos. 59

Tabela 8 - Coeficientes de variação e exatidão para as três diluições realizadas em uma amostra de fluido oral contendo $250 \mathrm{ng} / \mathrm{mL}$ de cocaína.

Tabela 9 - Coeficientes de variação e exatidão para as três diluições realizadas em uma amostra de fluido oral contendo $250 \mathrm{ng} / \mathrm{mL}$ de $\Delta 9-\mathrm{THC}$.

Tabela 10 - Coeficientes de variação e exatidão para as três diluições realizadas em uma amostra de fluido oral contendo $300 \mathrm{ng} / \mathrm{mL}$ de anfetamina. 61

Tabela 11 - Quantidade de amostras positivas para cada substância analisada nas análises de triagem em amostras de fluido oral de motoristas de caminhão $(\mathrm{n}=48)$ no estado de São Paulo

Tabela 12 - Amostras de fluido oral, coletadas de motoristas de caminhão que trafegavam em rodovias do estado de São Paulo, positivas na análise de confirmação por GC/MS e UPLC-MS/MS ( $n=40$ ). 63 Tabela 13 - Distribuição das características sociodemográficas e ocupacionais de motoristas de caminhão abordados em rodovias do estado de São Paulo com amostras de fluido oral positivas $(n=40)$ e com amostras negativas $(n=722) \ldots 64$ 


\section{Lista de quadros}

Quadro 1 - Formas de administração da cocaína e características de cada uma delas quanto à velocidade de absorção, início dos efeitos e biodisponibilidade da substância. 22

Quadro 2 - Características das matrizes biológicas sangue, fluido oral, urina e cabelo na identificação de droga de abuso.

Quadro 3 - Datas, locais e quantidade de amostras de fluido oral coletadas de motoristas de caminhão em cada dia de CSR.

Quadro 4 - Condições de elevação e controle de temperatura no cromatógrafo gasoso para o método de detecção da cocaína.

Quadro 5 - Condições de elevação e controle de temperatura no cromatógrafo gasoso para o método de deteç̧ão de $\triangle 9-T H C$.

Quadro 6 - Condições de elevação e controle de temperatura no cromatógrafo gasoso para o método de detecção de anfetamina.

Quadro 7 - Concentrações dos controles de qualidade baixo (CQB), médio (CQM) e alto (CQA) para a validação dos métodos de confirmação para cocaína, anfetamina e $\triangle 9$-THC.

Quadro 8 - Valores de limite de detecção e limite de quantificação para os métodos de confirmação para cocaína, anfetamina e $\Delta 9$-THC. 54 Quadro 9 - Número de participantes que relataram o uso das substâncias pesquisadas na semana, mês ou ano anterior às coletas e há mais de um ano da coleta, dentre aqueles que apresentaram resultados positivos para alguma substância nas análises confirmatórias $(n=40)$. 


\section{Resumo}

Bombana HS. Análise de anfetamina, cocaína e tetrahidrocanabinol em fluido oral de motoristas de caminhão que trafegam em rodovias do estado de São Paulo [Dissertação]. São Paulo: Faculdade de Medicina, Universidade de São Paulo; 2016.

No Brasil, em 2014, os acidentes de trânsito contabilizaram mais de 44 mil óbitos. Já foi relatado na literatura científica a relação entre o uso de drogas por motoristas de caminhão a fim de manterem a exaustiva jornada de trabalho a que são submetidos. O presente estudo teve como objetivo avaliar a frequência do uso de drogas ilícitas por motoristas de caminhão através de análises toxicológicas em amostras de fluido oral. Motoristas de caminhão foram abordados de forma aleatória por policiais rodoviários federais e convidados a participar dos Comandos de Saúde nas Rodovias, evento de promoção à saúde dos caminhoneiros. Os motoristas que aceitaram participar do estudo doaram uma amostra de fluido oral, coletado com o dispositivo Quantisal ${ }^{\mathrm{TM}}$, e responderam a um questionário estruturado para coleta de dados sociodemográficos. As amostras de fluido oral foram submetidas à análise de triagem para cocaína, anfetamina e $\Delta 9$-tetrahidrocanabinol ( $\triangle 9$-THC) por ELISA, sendo esse estudo pioneiro na utilização dessa técnica para triagem de amostras de fluido oral no trânsito. As amostras que apresentaram resultados positivos foram confirmadas por cromatografia gasosa acoplada à espectrometria de massas (GC-MS). No período de desenvolvimento desse estudo foi possível o envio das amostras positivas na etapa de triagem para o Instituto Norueguês de Saúde Pública para confirmação por cromatografia líquida de ultra eficiência acoplada à espectrometria de massas em tandem (UPLC-MS/MS). Além das três substâncias já pesquisadas no estudo foram analisadas a presença de outras 29, dentre drogas ilícitas e medicamentos psicoativos. Foram incluídos 762 motoristas. Das amostras analisadas, 5,2\% $(n=40)$ apresentaram resultado positivo para algum tipo das drogas estudadas. A cocaína foi a droga mais encontrada $(n=16)$, seguida pela anfetamina $(n=11)$ e $\Delta 9-T H C(n=4)$. Ainda, três amostras apresentaram resultados positivos para cocaína e $\triangle 9-T H C$ e uma amostra para cocaína e anfetamina. Além da cocaína, anfetamina e $\Delta 9$-THC, com a confirmação por UPLC-MS/MS foram detectados outros fármacos psicoativos, o meprobamato e o alprazolam, (duas amostras testaram positivo para anfetamina e meprobamato uma para anfetamina e alprazolam e outra amostra para cocaína e meprobamato). Os motoristas com amostras positivas eram mais jovens, com menos escolaridade, mais inexperientes, possuíam uma jornada de trabalho mais extensa e percorriam percursos mais longos. Esse fato alerta, sem dúvida, a necessidade da ampliação de estudos nacionais sobre o uso de substâncias psicoativas, incluindo as ilícitas e medicamentos, para melhor entendimento na comunidade científica e permitindo a implementação de políticas públicas voltadas à prevenção e fiscalização do uso dessas 
substâncias, com o objetivo de reduzir a morbimortalidade resultante dos acidentes de trânsito nacionais.

Descritores: drogas ilícitas; acidentes de trânsito; cocaína; anfetaminas; cannabis; caminhões; estradas. 


\begin{abstract}
Bombana HS. Analysis of amphetamine, cocaine and cannabis in oral fluid from truck drivers driving through highways in the state of Sao Paulo [Dissertation]. São Paulo: "Faculdade de Medicina, Universidade de São Paulo"; 2016.

In Brazil, in 2014 it caused more than 44 thousand deaths. In Brazil is already described in the literature the use of psychoactive substances by truck drivers to maintain their extensive work schedule and stay awake for several hours. Important highways cross through Sao Paulo to other regions from Brazil and to countries from Latin America. This study aims to demonstrate the prevalence of illicit drug use by truck drivers on the State of Sao Paulo through toxicological analyses on oral fluid. Truck drivers were randomly stopped by police officers on federal roads during morning hours. Oral fluid samples were collected using the Quantisal $^{\mathrm{TM}}$ device. In addition, a questionnaire concerning sociodemographic characteristics and health information was administered. Oral fluid samples were screened for amphetamine, cocaine, and tetrahydrocannabinol ( $\triangle 9$-THC) by ELISA. The samples were confirmed by GC-MS, using validated methods for the substances of interest. During the development of this study we had the opportunity to send the positive samples to the Norwegian Institute of Public Health for confirmation using UPLC-MS/MS. Besides cocaine, amphetamine and $\triangle 9$-THC the samples were tested for others 29 samples, including illicit drugs and psychoactive medicines. 762 drivers agreed to participate. Of the total samples $5.2 \%(n=40)$ tested positive for drugs. Cocaine was the most found drug $(n=$ $16)$, followed by amphetamine $(n=11)$ and $\triangle 9$-THC $(n=4)$. Furthermore, three samples tested positive for cocaine and $\triangle 9-T H C$ and one sample for cocaine and amphetamine. The confirmation using UPLC-MS/MS pointed another two substances that were not tested previously, meprobamate and alprazolam (two samples tested positive for amphetamine and meprobamate, one for amphetamine and alprazolam and another one for cocaine and meprobamate). Drivers presenting positive samples were younger, with less education, less experienced, had a longer work schedule and drove longer distances. This fact shows that, undoubtedly, there is need for more national studies regarding the use of psychoactive substances, illicit and medicines, for a better understand by the scientific community and those responsible for implementation of public policies aiming the control of the use of these substances, in order to, one day, we were able to indeed reduce traffic accidents mortality in our country.
\end{abstract}

Descriptors: street drugs; accidents, traffic; cocaine; amphetamines; cannabis; trucks; roads. 


\section{INTRODUCẼO}




\section{Introdução}

Segundo a Organização Mundial da Saúde (OMS), os acidentes de trânsito (AT) atingiram números alarmantes, sendo responsáveis por 1 milhão e 250 mil mortes em 2013, em todo o mundo. Além disso, para cada morte ocasionada existem outras 20 pessoas que ficam feridas, muitas vezes gravemente, devido aos AT, gerando uma soma de 20 a 50 milhões de vítimas não fatais, resultando um grande impacto econômico e social. Estes números elevam os AT à nona colocação de causa de mortes entre a população geral e a primeira entre a faixa etária de 15 a 29 anos. A OMS estima que, se nenhuma medida for tomada, em 2030 os AT irão ocupar a sétima causa de morte com 2 milhões e 400 mil óbitos anuais ${ }^{1}$.

Os países de baixa e média renda são os maiores responsáveis pelos altos números de mortes em AT. A crescente evolução da motorização desses países não conseguiu ser acompanhada pelo desenvolvimento da infraestrutura e fiscalização. Os países de média renda, incluindo o Brasil, representam 70\% da população mundial e possuem $53 \%$ de toda a frota mundial registrada, apesar disto são responsáveis por $74 \%$ dos AT (Figura 1). Isto demonstra uma grande desproporção entre os números de AT e o nível de motorização destes países, principalmente pela falta de investimentos em segurança viária e fiscalização'. 


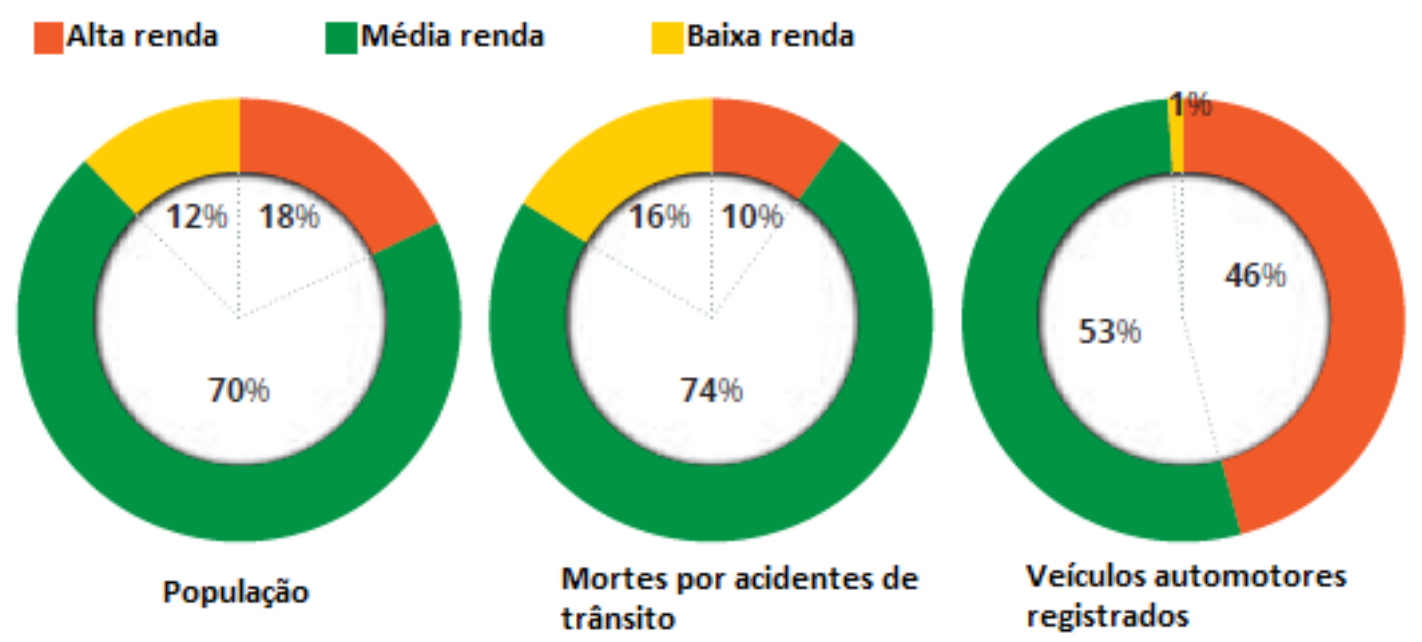

Figura 1. Porcentagem de população, mortes por acidentes de trânsito e veículos registrados, separados de acordo com o perfil econômico dos países. Adaptado de OMS, 2015.

Uma forma para avaliação da quantidade de mortes por AT em um país é através da taxa de mortalidade a cada 100 mil habitantes. Mundialmente essa taxa se encontra em 17,5 mortes a cada 100 mil habitantes. Em países de baixa renda, aumenta drasticamente para 24,1 mortes e em países de média renda encontra-se em 18,5 mortes a cada 100 mil habitantes. No Brasil, observamos uma discrepância entre a faixa econômica em que se encontra (país de média renda) e a taxa de mortalidade, sendo mais de 23,4 mortes a cada 100 mil habitantes em $2013^{1}$, estando mais próxima de países de baixa renda ao invés da faixa econômica em que se insere. Em países da União Europeia e nos EUA, a tendência é a diminuição dessa taxa ao longo dos anos. Por outro lado, no Brasil, existe uma constância, sem haver decaimentos significativos ${ }^{2}$. $\mathrm{Na}$ Noruega, o uso de álcool por motoristas é regulado desde 1936³. Além disso, é proibido por lei um motorista de caminhão consumir álcool ou qualquer outra substância psicoativa em até 8 horas antes de dirigir ${ }^{4}$. Estas ações contribuem para a baixíssima taxa de mortalidade por AT, de apenas 3,8 mortes a cada 100 mil habitantes ${ }^{1}$ (Figura 2). 


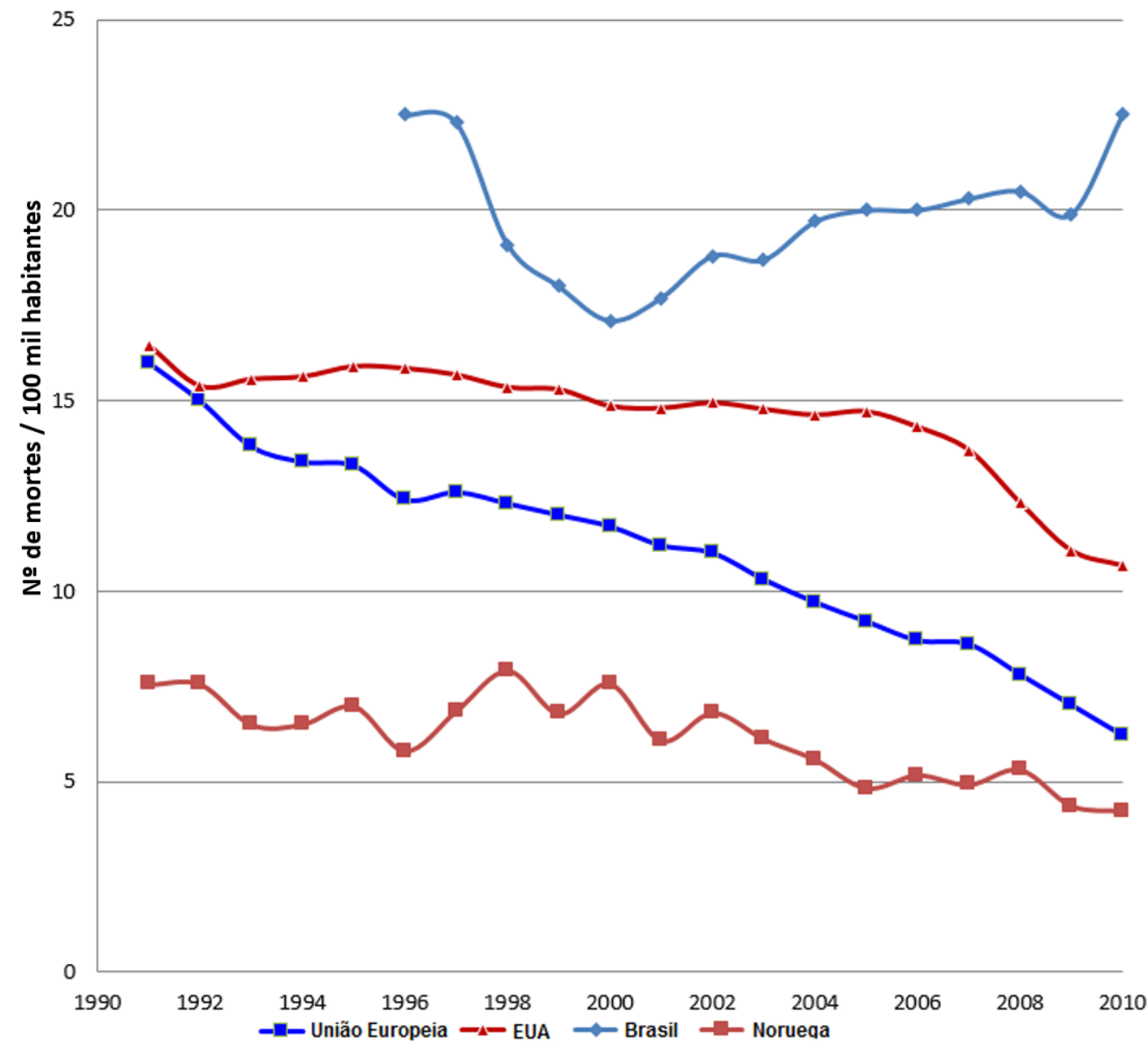

Figura 2. Taxa de mortalidade por acidentes de trânsito a cada 100.000 habitantes, no Brasil, União Europeia, Estados Unidos da América e Noruega entre os anos de 1990 e $2010^{*}$.

No Brasil, em 2014, segundo dados do Ministério da Saúde (MS), as causas externas constituíram a terceira causa de morte em todo o país, chegando a 155.610 mortes, ficando atrás apenas de neoplasias e doenças do aparelho circulatório. Dentre as causas externas, os AT foram responsáveis por mais de 44 mil óbitos, ficando em segundo lugar nessa categoria²

O Brasil possui 1.720 .613 quilômetros de rodovias, entre rodovias estaduais e federais, sendo apenas pouco mais de 200 mil quilômetros pavimentados; destas, aproximadamente 70 mil quilômetros são fiscalizados pela Policia Rodoviária Federal (PRF). No ano de 2014, ocorreram nas rodovias federais aproximadamente 170 mil acidentes, incluindo os acidentes com vítimas

* Gjerde H. (Instituto Norueguês de Saúde Pública, Oslo, Noruega). Comunicação pessoal; 2014. 
e os sem vítimas fatais. Nesse ano, os AT ocorridos nas rodovias federais brasileiras geraram um custo para a sociedade de $R \$ 12,3$ bilhões, sendo que $64,7 \%$ desses custos estavam associados às vítimas dos acidentes, como cuidados com a saúde e perda de produção devido às lesões ou morte, e 34,7\% estavam associados aos veículos, como danos materiais e perda de cargas, além dos procedimentos de remoção dos veículos acidentados ${ }^{5}$.

O estado de São Paulo é considerado um dos estados mais importantes para a distribuição de carga no país, por possuir rodovias que ligam tanto as outras regiões do Brasil como também outros países da América Latina ${ }^{6}$, apresentando a segunda maior malha rodoviária do país, ficando atrás apenas de Minas Gerais ${ }^{7,8}$. Por outro lado, ocupa o posto de estado com maior número de óbitos ocasionados pelos AT. Segundo dados do MS, foram mais de 7 mil mortes em $2014^{2}$.

Segundo o Departamento Nacional de Trânsito (DENATRAN), em 2015 a frota brasileira era composta por aproximadamente 89.400 .000 veículos, sendo mais de 8 milhões $(9,16 \%)$ de caminhões. Estes são responsáveis por transportar cerca de $60 \%$ dos produtos produzidos no país, o que torna a malha rodoviária nacional a maior forma de escoamento de cargas ${ }^{9,10}$.

Motoristas de caminhão são um grupo bastante suscetível ao uso de drogas, pelo fato de possuírem uma jornada de trabalho extensa e cansativa. A fadiga e o cansaço são descritos como fatores que contribuem de maneira significativa na ocorrência de AT. Além das viagens, os motoristas de caminhão trabalham também carregando e descarregando os caminhões, o que agrava o desgaste e estresse desses profissionais e, consequentemente, pode aumentar o uso de drogas estimuladoras para ficar em estado de alerta ${ }^{11,12}$. Além da rotina de trabalho, outro fator que influencia o uso de álcool e drogas é a solidão a que os caminhoneiros são submetidos, muitas vezes viajando sozinhos e ficando longe da família ${ }^{13}$. Em estudo de 2008 realizado em Fortaleza, um grupo de motoristas de caminhão foi analisado para a presença de depressão. Foi encontrado que $13,6 \%$ dos motoristas participantes apresentaram sinais de depressão, variando de leve a grave. Além disso, uma associação entre depressão e o uso de estimulantes foi detectada. Muitas vezes o uso de 
substâncias é feito para se obter um alivio momentâneo dos sintomas da depressão, mas levando a efeitos deletérios a longo prazo ${ }^{14}$. A depressão que acomete os motoristas de caminhão é encontrada com maior frequência em motoristas mais jovens e pode estar relacionada com a falta de experiência, 0 desconhecimento das condições de trabalho, nervosismo durante a jornada de trabalho e uma dificuldade de se adaptar às condições a que são submetidos na estrada ${ }^{15}$.

Visando uma melhoria no cenário nacional em relação às bases científicas relacionadas ao uso de drogas e a condução veicular, além da necessidade da realização de estudos epidemiológicos com o objetivo de atender as recomendações da ONU relacionadas ao conhecimento dessa questão, foi delineado o presente estudo. Com a coleta de amostras de fluido oral de motoristas de caminhão que trafegam no estado de São Paulo e análises toxicológicas, além das informações obtidas através da aplicação de um questionário estruturado, foi possível traçar um perfil dos motoristas que realizaram uso recente ou que até mesmo estavam sob efeito das substâncias estudadas. 
REVISÃO DA

LTERATURA 


\section{Revisão da Literatura}

\subsection{Cocaína}

A cocaína é o principal constituinte ativo encontrado nas folhas da Erythroxylon coca, planta originária da zona tropical dos Andes. Em países andinos como Colômbia, Bolívia e Peru, a folha de coca é utilizada desde o século VI a.C. pelos indígenas locais para melhor suportar o esforço físico e a fadiga causada pela altitude ${ }^{16}$.

Os primeiros estudos científicos datam do século XIX com Friedrich Wöehler e Albert Niemann, sendo esse o primeiro a isolar e caracterizar a cocaína das folhas de coca. O psicanalista Sigmund Freud passou a receitar cocaína a seus pacientes para o tratamento de depressão e dependência à morfina, mas após perceber os efeitos adversos como a dependência passou a denominá-la "terceiro flagelo", após o álcool e a heroína ${ }^{17}$.

As folhas, após maceração, são convertidas em pasta de coca, que constitui a forma de tráfico e é utilizada para produzir o cloridrato de cocaína, sal mais comumente empregado na autoadministração ${ }^{16}$.

Existem quatro principais formas de autoadministração da cocaína. A principal delas é a intranasal, inalando-se o pó do cloridrato de cocaína. Esta via possui uma baixa velocidade de absorção devido às propriedades vasoconstritoras da substância, iniciando-se os efeitos de 10 a 15 minutos após o consumo. A biodisponibilidade da substância por essa via encontra-se na faixa de 20 a $30 \%$ devido à grande parte que é deglutida durante a aspiração nasal ${ }^{18,19}$.

Outra forma de administração é a cocaína base livre, conhecido como crack. É obtido através do aquecimento da solução aquosa do cloridrato de cocaína com substâncias básicas e resfriado logo em seguida, formando-se pedras. Esta forma possui baixo ponto de fusão, volatilizando-se quando aquecida, o que permite o consumo através das vias respiratórias. Após fumada, a droga é rapidamente absorvida pelos alvéolos, produzindo efeitos em poucos segundos após administração ${ }^{19,20}$. 
A via intravenosa possui características semelhantes à via respiratória quanto à velocidade de absorção e duração dos efeitos, sendo esses feitos mais rápidos e intensos nesta forma de administração ${ }^{18}$.

O consumo através da via oral é realizado mascando-se folhas das plantas ou pelo consumo de chás. A absorção é retardada pela ionização da cocaína devido à acidez estomacal, atingindo pico plasmático após 45 a 60 minutos ${ }^{21}$.

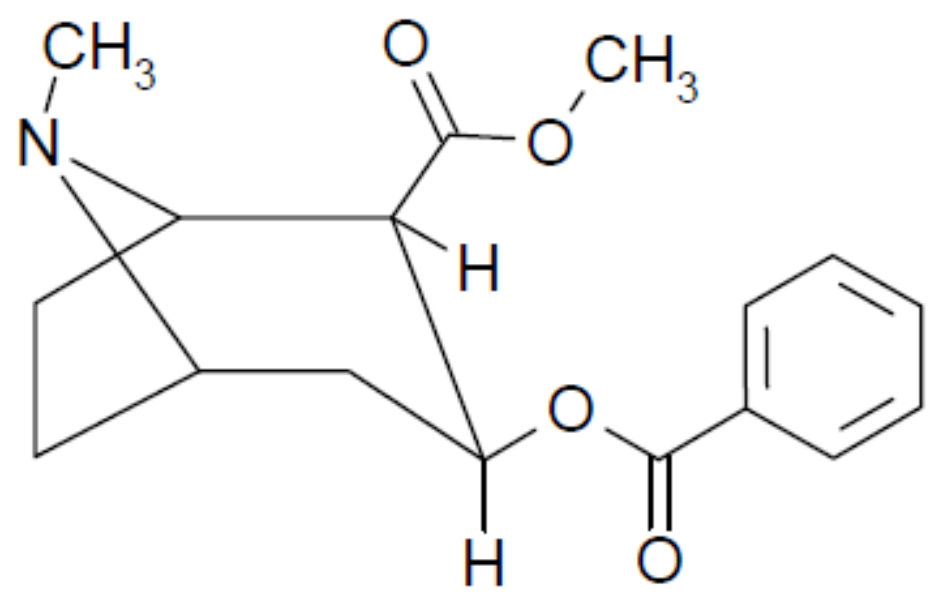

Figura 3. Estrutura química da molécula de cocaína.

Quadro 1 - Formas de administração da cocaína e características de cada uma delas quanto à velocidade de absorção, início dos efeitos e biodisponibilidade da substância.

\begin{tabular}{cccc}
$\begin{array}{c}\text { Via de } \\
\text { administração }\end{array}$ & $\begin{array}{c}\text { Velocidade de } \\
\text { absorção }\end{array}$ & $\begin{array}{c}\text { Início dos } \\
\text { efeitos }\end{array}$ & Biodisponibilidade \\
\hline Respiratória & Alta & $\begin{array}{c}\text { Poucos } \\
\text { segundos }\end{array}$ & $70 \%$ \\
Intravenosa & Alta & $3-5 \mathrm{~min}$ & $100 \%$ \\
Intranasal & Baixa & $10-15 \mathrm{~min}$ & $20-30 \%$ \\
Oral & Baixa & $45-60 \mathrm{~min}$ & $20 \%$
\end{tabular}


A cocaína é um potente analgésico e atua como um agente simpatomimético com efeitos estimulantes no sistema nervoso central (SNC), sendo considerado o mais potente estimulante natural. Esse efeito é causado pela ligação aos receptores dopaminérgicos D1 e D2 pós-sinápticos; a droga bloqueia a recaptura da dopamina nos terminais pré-sinápticos, causando um aumento extracelular desse neurotransmissor. Devido ao aumento da dopamina, os seguintes efeitos podem ser causados: euforia imediata, sensação de bemestar, ilusão de onipotência, grande autoconfiança, melhora da autoestima. Ainda pode causar diminuição do sono e do apetite. Os efeitos podem durar até 2 horas após o consumo, apresentando pico de ação após 20 a 30 minutos, dependendo da via de administração e da dose ${ }^{17}$.

O motorista sob efeito da cocaína pode ter um melhor desempenho na direção durante a fase de euforia. Entretanto, está mais propenso a assumir comportamentos de risco, o que pode levar a um envolvimento maior em AT. O prejuízo no desempenho observado pode ser em razão da perda de concentração e atenção e maior sensibilidade à luz, em virtude das pupilas dilatadas. Além disso, sintomas psicológicos, tais como paranoia e alucinações, podem influenciar no comportamento na direção 22 .

\subsection{Anfetaminas}

As anfetaminas são drogas sintéticas que, assim como a cocaína, são estimulantes do SNC. A primeira anfetamina foi sintetizada em 1887, mas somente a partir da década de 1920 foi largamente utilizada com fins terapêuticos nos tratamentos da obesidade, narcolepsia, hipotensão e síndrome de hiperatividade infantil. Na década de 1940 houve abuso no uso de anfetaminas que eram encontradas em descongestionantes nasais; na Segunda Guerra Mundial foi amplamente utilizada por soldados combatentes para retardar o aparecimento de fadiga, aumentar o estado de alerta, elevar o humor e aumentar a resistência; já na década de 1960 começou a ser usada por esportistas por suas propriedades ergogênicas e, na década de 1970, por estudantes universitários ${ }^{16,23}$. 
A anfetamina atua como amina simpatomimética ao nível dos receptores $\alpha$ e $\beta$-adrenérgicos. Os efeitos estimulantes da anfetamina resultam da similaridade estrutural com a dopamina e norepinefrina, funcionando assim, como um falso neurotransmissor. Atua na liberação direta dos neurotransmissores das vesículas sinápticas, bem como inibição da receptação destes, com consequente aumento da concentração sináptica. Além disso, as anfetaminas são inibidoras da monoaminoxidase (MAO), enzima responsável pela oxidação da norepinefrina e serotonina e dopamina. Como consequência fisiopatológica tem-se uma intensa estimulação central e da atividade motora ${ }^{17}$.

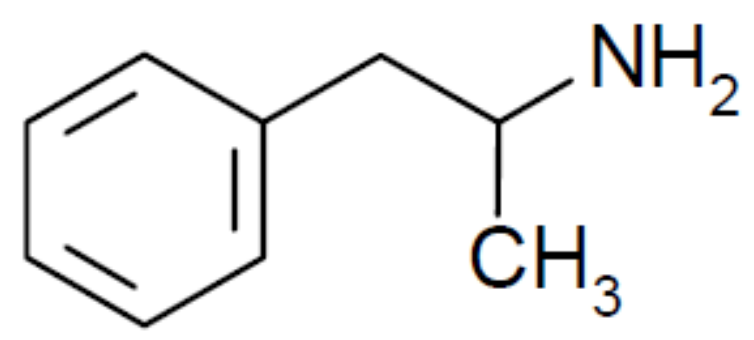

Figura 4. Estrutura química da molécula de anfetamina

Em baixas concentrações causam euforia, bem-estar aumento da capacidade física e intelectual, e diminuição da fadiga e do apetite. Em doses maiores podem provocar irritação, insônia, nervosismo e inquietação. Em indivíduos hipersensíveis, produzem alucinações, delírios e até mesmo, convulsões. Essa classe de drogas aumenta a frequência cardíaca, a respiração, a pressão arterial e pode levar a arritmias cardíacas. $O$ uso a longo prazo pode causar alterações neuroquímicas e neuroanatômicas que podem causar supressão da fase REM (rapid eye movement) do sono, estágio do sono associado com sono profundo e sonhos 23,24 .

No Brasil, os anfetamínicos eram comercializados como medicamentos moderadores do apetite para tratamento da obesidade e para indivíduos que sofriam de distúrbios psicológicos. Em 2014, a Agência Nacional de Vigilância Sanitária (ANVISA) publicou a Resolução № 50 que controla a comercialização, prescrição e dispensação de medicamentos que contenham anfepramona, 
femproporex, mazindol e sibutramina ${ }^{25}$. A pessoa sob efeito dessas substâncias realiza atividades por um período maior e com sensação de menor cansaço, já que nas primeiras horas a sensação de bem estar é grande, porém, após esses efeitos, vem a irritabilidade e o sono incontrolável ${ }^{26}$.

As anfetaminas são popularmente denominadas "rebites" pelos motoristas de caminhão e são utilizadas por aqueles que dirigem durante várias horas seguidas sem descanso, a fim de cumprir prazos pré-determinados ${ }^{27}$. Depois da fase inicial euforizante, é comum o aparecimento de uma fase secundária depressiva, com fadiga, torpor, sonolência e inibição mental, conhecida como efeito rebote.

\subsection{Cannabis}

A partir da planta Cannabis sativa, a qual cresce facilmente em regiões tropicais, subtropicais e temperadas, são realizadas diversas preparações utilizando suas folhas e flores. Nessa planta já foram isolados e identificados mais de 480 compostos, dentre canabinol, canabidiol, canabigerol e vários isômeros do tetrahidrocanabinol. Um desses isômeros, o $\Delta 9$-tetrahidrocanabinol $(\triangle 9-\mathrm{THC})$ é o princípio ativo responsável pelos efeitos psicoativos observados pelo consumo da planta ${ }^{23,28}$.

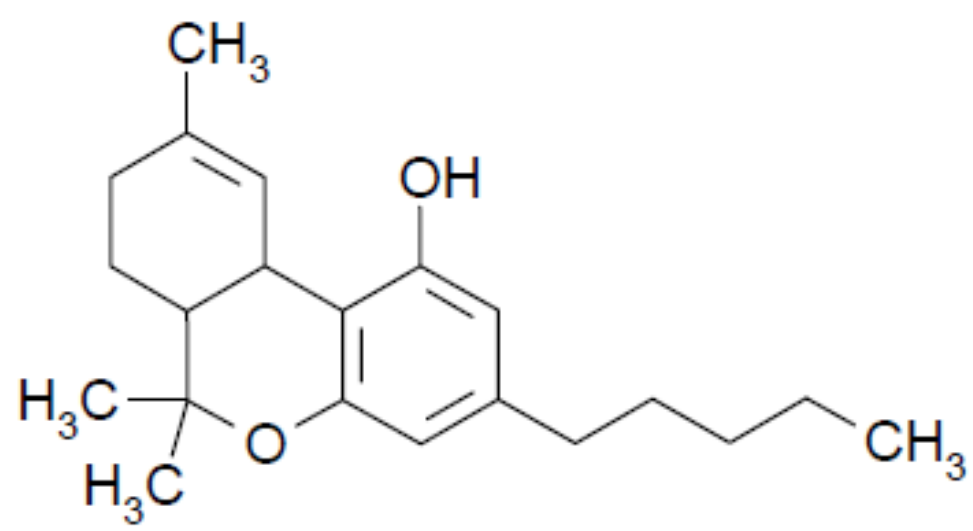

Figura 5. Estrutura química da molécula do $\Delta 9$-Tetrahidrocanabinol ( $\Delta 9$-THC) 
São várias as formas de apresentação e consumo da droga. O mais frequente é o cigarro produzido com várias partes da planta que, após secas, são picadas e fumadas. Há também o haxixe que é constituído da resina extraída das inflorescências da planta, possuindo coloração marrom-escura e consistência de uma pasta semissólida; também é consumido na forma de cigarro. Outra forma também bastante conhecida é o óleo de haxixe que é um óleo negro e viscoso com odor característico. É extraído da planta ou de sua resina e tem alto teor de $\Delta 9-\mathrm{THC}(10 \text { a } 30 \%)^{17}$.

Existem duas formas de consumo da cannabis, através da via inalatória e pela via oral. O uso oral apresenta efeitos com início tardio (30 a $60 \mathrm{~min}$ ), mais prolongados (2 a 3 horas após ingestão) e com menor intensidade. Através dessa via, a disponibilidade do $\triangle 9$-THC é menor devido ao efeito de primeira passagem, sendo necessária uma dose maior para que os efeitos apareçam. Nesse caso os produtos são consumidos misturados a alimentos, bebidas ou cápsulas de gelatina ${ }^{18}$.

Uma vez absorvido, o $\Delta$ 9-THC é rapidamente distribuído aos órgãos e tecidos com alto teor de lipídeos, devido à sua alta lipossolubilidade. Apenas uma pequena porção dessa substância é distribuída na corrente sanguínea na forma livre, de 94 a $99 \%$ do $\triangle 9$-THC circula ligado a proteínas plasmáticas. Devido a esse fato, apenas cerca de $1 \%$ do $\triangle 9$-THC absorvido atravessa a barreira hematoencefálica chegando ao cérebro. A via de administração endovenosa não é utilizada devido à insolubilidade dos canabinoides em meio aquoso ${ }^{17,24}$.

O $\triangle 9$-THC liga-se aos receptores canabinoides CB1 e CB2 presentes no organismo. O primeiro é encontrado em algumas áreas do SNC, como córtex, hipocampo, cerebelo e gânglios basais. Esses locais são responsáveis pelos efeitos de cognição, aprendizagem, memória, equilíbrio e coordenação motora, respectivamente. Já os receptores CB2 estão localizados nas células do sistema imune, monócitos e linfócitos $\mathrm{B}$ e $\mathrm{T}^{28}$.

Os efeitos observados após o uso dos canabinoides está relacionado com a dose consumida, suscetibilidade do usuário, via de administração e fatores 
ambientais. Os principais efeitos que podem ser verificados são: efeito inicial de euforia, agitação, seguido de um período de relaxamento e tranquilidade, taquicardia, diminuição da salivação, comprometimento do equilíbrio, coordenação, atenção e memória recente, aumento do apetite e hiperemia das conjuntivas. Em doses mais elevadas podem aparecer efeitos semelhantes aos alucinógenos ${ }^{17,21,23}$.

\subsection{Drogas de abuso na direção veicular}

\subsubsection{Efeitos prejudiciais causados nos condutores}

As causas para o acontecimento de AT são multifatoriais, envolvendo o veículo (falhas mecânicas), distrações dentro do veículo (uso de celular, distrações pelos passageiros), condições climáticas e da via. Também devem ser considerados a idade do condutor, bem como sua experiência, além do uso de qualquer substância que possa alterar as percepções do motorista ${ }^{29}$.

O acontecimento de AT pode estar muito relacionado com o uso de substâncias psicoativas que alteram as percepções dos motoristas afetando negativamente o ato de dirigir. Em 2011, Stoduto et al. realizaram um estudo que identificou, por relatos, que usuários de cocaína possuíam 18,7\% de chance de se envolver em colisões nos doze meses anteriores à pesquisa, enquanto que, não usuários, apenas 7,4\% ${ }^{30}$. Da mesma maneira, Drummer et al. (2007) determinaram que condutores que apresentavam resultados positivos para drogas psicotrópicas eram significantemente mais prováveis de serem culpados por colisões do que aqueles que não tinham utilizado drogas ${ }^{31}$.

O uso de anfetamina por motoristas está relacionado com a maior probabilidade de ocorrência de AT, dentre diversas drogas ${ }^{32}$. Os usuários dessa substância apresentam 5,6\% mais chance de se envolver em acidentes fatais do que os não usuários. O mesmo ocorre com a cocaína, 2,9\% e cannabis, 1,2\% ${ }^{33}$. 
Estudo de Gates et al. (2013), mostrou que aqueles motoristas de caminhão que ingerem substâncias estimulantes para ficarem acordados e conseguirem dirigir são mais propensos a realizar atos que aumentam a probabilidade de ocorrência de AT. Dentre estes atos estão: dirigir acima da velocidade permitida, ultrapassar sinal vermelho e dirigir em zigue-zague. Neste estudo também foi discutido o fato de apenas médias e altas concentrações de estimulantes influenciarem negativamente 0 ato de dirigir, enquanto que concentrações baixas poderiam melhorar o desempenho ao volante. Segundo os autores, os estimulantes são responsáveis pela ocorrência do efeito rebote, o qual ocorre quando o efeito da substância cessa e o motorista é acometido por uma súbita exaustão. Durante este período, as concentrações da substância no organismo são baixas, contrariando a hipótese de que somente altas e médias concentrações são deletérias ${ }^{34}$.

Em um estudo canadense, o uso de álcool, cocaína e maconha foi avaliado na culpabilidade por um acidente de trânsito ter ocorrido. Foi constatado que o uso dessas substâncias psicotrópicas não só diminui a habilidade de não se envolver em acidentes, como também aumenta a probabilidade do condutor de agir de maneira mais perigosa e de se envolver em situações de alta periculosidade ${ }^{35}$.

\subsubsection{Prevalência do uso de drogas por condutores}

Ao se avaliar a frequência do uso de substâncias psicoativas por motoristas envolvidos em AT, fatais ou não, é possível encontrar altos números de amostras positivas. Drummer et al. (2012) relataram que 35\% dos motoristas admitidos em salas de emergências apresentaram resultados positivos para algum tipo de substância, tais como: THC, 3,4-metilenodioximetanfetamina (MDMA), anfetamina, benzodiazepínicos, opioides, antidepressivos e antipsicóticos. Quando analisado a presença de álcool o número sobe ainda mais, atingindo $52 \%$ dos motoristas ${ }^{36}$. Em estudo semelhante conduzido na Noruega, observou-se que $21,9 \%$ dos motoristas feridos em acidentes de 
trânsito, sem vítimas fatais, apresentavam algum tipo de substância psicotrópica, sendo o álcool o mais prevalente, seguido pelos estimulantes, como cocaína e anfetamina $^{37}$. Na Suécia e demais países nórdicos, as anfetaminas têm sido a classe de drogas de abuso de uso mais frequente desde os anos 1960. Além de serem mais consumidas, também são responsáveis por AT, sendo encontrada em mais de $80 \%$ das vítimas fatais ${ }^{38}$.

No Brasil, o único estudo nacional sobre a prevalência do uso de drogas por motoristas é o estudo "Uso de bebidas alcoólicas e outras drogas nas rodovias brasileiras e outros estudos" promovido pela Secretaria Nacional de Políticas sobre Drogas (SENAD) e publicado em 2010. Neste estudo, foram incluídos motoristas profissionais e particulares e foram realizadas coletas de fluido oral em rodovias que cruzam as 27 capitais brasileiras. Das 3398 amostras coletadas, foi encontrada uma positividade de 4,6\% ( $N=150)$ para alguma substância pesquisada. A droga mais encontrada foi a cocaína, 2,05\%, seguida pela cannabis $1,5 \%$ e anfetaminas $1,2 \%{ }^{39}$.

Leyton et al. (2012) realizaram um estudo envolvendo motoristas de caminhão. Amostras de urina foram coletadas de motoristas que trafegavam no estado de São Paulo. Dos 452 voluntários que participaram da pesquisa, 9,3\% apresentaram positividade para algum tipo de droga. A substância mais encontrada foi a anfetamina (5,8\%), seguida da cocaína e $\Delta 9-\mathrm{THC}^{13}$. Em estudo semelhante, também envolvendo motoristas de caminhão no estado de São Paulo, mas envolvendo análises toxicológicas em fluido oral, foi encontrado uma frequência de $3,1 \%$ de positividade para alguma substância psicoativa, dentre as 1250 amostras analisadas ${ }^{40}$.

\subsection{Fluido oral na detecção de drogas de abuso}

Em 1993, durante um congresso da Academia de Ciências de Nova Iorque, sobre testes em saliva, foi estabelecido que o termo "saliva" deve ser utilizado para secreções das glândulas salivares que são obtidas diretamente 
das glândulas e o termo "fluido oral" para o fluido obtido com auxílio de materiais absorventes na cavidade bucal ${ }^{41}$.

Desta maneira, o fluido oral corresponde não só à saliva, mas também a outras secreções presentes na cavidade bucal, restos celulares, bactérias, transudados mucosos e restos alimentares. A saliva é excretada principalmente por três glândulas: a parótida, submaxilar e sublingual e também por outras glândulas menores. Em repouso, a maior parte da saliva é produzida pela glândula submaxilar $(70 \%)$, seguida da parótida $(25 \%)$ e sublingual $(5 \%)$. Quando há estimulação a secreção da glândula parótida aumenta, atingindo aproximadamente $50 \%$ de toda saliva produzida ${ }^{41,42}$.

O fluido oral possui baixa quantidade de proteínas $(0,3 \%)$ e o fluxo de secreção pode variar de acordo com as estimulações ao longo do dia, podendo chegar a até $1,5 \mathrm{~L}$. O uso de algumas drogas, como maconha e anfetaminas, pode diminuir o fluxo de secreção de fluido oral, fazendo com o tempo de coleta se estenda ${ }^{42,43}$.

As glândulas salivares são muito perfundidas, ou seja, muito irrigadas por pequenos vasos sanguíneos. Devido a este fato, a transferência de uma substância da corrente sanguínea para a glândula salivar ocorre em poucos minutos após administração intravenosa, por via oral ou após inalação. A transferência da droga ocorre predominantemente por difusão passiva através da bicamada fosfolipídica das células dos túbulos secretores. A difusão das drogas requer que a molécula seja lipossolúvel, não ionizada e não esteja ligada a proteínas plasmáticas. Desta maneira, a concentração da droga no fluido oral representa a fração livre e não ionizada da droga circulante no sangue. As características químicas da droga, $\mathrm{pK}$ a, o pH salivar, quantidade de droga não ionizada e a ligação da droga com proteínas são exemplos de características que podem alterar a concentração da droga no fluido oral|42,44. $\mathrm{O} \mathrm{pH}$ salivar é inversamente proporcional ao fluxo de secreção e à absorção de sódio nos túbulos salivares. Quanto mais rápida ocorre a secreção salivar, menos sódio é reabsorvido e $\circ \mathrm{pH}$ aumenta. Desta forma, uma salivação sem estimulação possui menor pH do que aquela coletada através de estimulação ${ }^{41}$. 
O fluido oral apresenta, normalmente, um $\mathrm{pH}$ menor do que o do plasma, por isso a relação saliva:plasma para drogas ácidas é menor do que a relação saliva:plasma para drogas básicas, resultando na maior concentração de drogas básicas no fluido oral ${ }^{41}$.

A detecção de drogas pode ser realizada em qualquer tecido ou fluido biológico, mas para a escolha da melhor matriz é necessário levar em consideração vários aspectos como: propósito da coleta, facilidade de coleta, taxa de recusa em fornecer a amostra, custo da análise, concentração e estabilidade da amostra ${ }^{43}$.

A utilização do fluido oral como matriz para detecção de drogas tem crescido nos últimos anos, sendo utilizada em ambiente de trabalho ${ }^{45}$, em fiscalização do uso de drogas por condutores ${ }^{46,47}$, em hospitais ${ }^{48}$ e clinicas de reabilitação ${ }^{49}$. A coleta desse material é realizada de maneira não invasiva, rápida, sem constrangimento e, como é feita na presença do pesquisador, as chances de adulteração são mínimas ${ }^{42}$.

Wong et al. conduziram um estudo em 2005 no qual foi avaliada a eficiência de adulterantes para fluido oral, vendidos comercialmente, para destruição de drogas de abuso. Além disso, foram realizados testes para verificar se alimentos, bebidas e produtos de higiene poderiam causar um resultado falso positivo. Foram utilizados dois adulterantes diferentes e um antisséptico bucal em voluntários que fizeram uso de substâncias psicoativas. Foi comprovado que nenhum dos três produtos foi capaz de destruir a droga, que foi detectada após o uso dos mesmos. Os autores relataram uma diminuição na concentração da droga no fluido oral, mas que foi atribuída à diluição da matriz e não à degradação da molécula da substância. Também foi relatado que alimentos, bebidas e produtos de higiene não produzem qualquer resultado falso positivo, tornando o fluido oral uma matriz de grande confiança na detecção de drogas de abuso ${ }^{50}$.

Outro fator importante a ser levado em consideração na escolha da matriz biológica é a janela de detecção de um analito, definido como o tempo decorrido entre a administração de uma dose única de uma substância e a detecção desta 
em uma matriz biológica ${ }^{51}$. O tempo de detecção de uma droga em fluido oral, após uma dose única, é bastante semelhante ao tempo de detecção em sangue, período este que é bem menor do que a detecção em urina. Dependendo da droga utilizada, esta pode ser detectada em alguns minutos no sangue e no fluido oral, mas na urina a detecção pode demorar mais tempo, dependendo da taxa de filtração do sangue e excreção urinária ${ }^{30,52}$. Já em amostras de cabelo uma substância pode ser identificada até 6 meses após o uso, dependendo do comprimento do fio analisado ${ }^{53}$. Entretanto, esse tipo de amostra pode sofrer contaminação externa e o analito ser prejudicado com o uso de produtos de higiene ou tinturas ${ }^{43}$.

Dentro do contexto de fiscalização e aplicação da Lei, o sangue é a matriz que deve ser coletada para verificar se o condutor está ou não sob efeito de drogas no momento que cometeu uma infração. Esta matriz é a única que reflete a real concentração da droga no cérebro, por isso é indicada para se verificar se o condutor está sob efeito da substância. Em estudos epidemiológicos o sangue pode ser utilizado, mas sua coleta não é fácil por ser extremamente invasiva, levando a altos índices de recusa, além disso, pode ser realizada somente por profissionais especializados ${ }^{43}$. O fluido oral reflete a circulação da droga ativa no sangue e, por ser um filtrado deste, fornece informações importantes sobre a concentração de drogas na corrente sanguínea ${ }^{54,55}$. Adotando-se valores semelhantes de cut-off pode-se afirmar que a concentração de uma droga no fluido oral reflete aquela presente no sangue ${ }^{43}$.

Cut-off (valor de corte) é um valor numérico, utilizado em análises toxicológicas e análises clínicas onde os resultados das amostras que estão abaixo deste valor são considerados negativos (não detectado) e os resultados acima desse valor são considerados positivos (detectado). O cut-off diminui a possibilidade de se detectar o uso de drogas ingeridas involuntariamente, de forma passiva. Também é utilizado para minimizar a detecção de drogas que foram usadas em períodos anteriores e aumentar a detecção de uso no período de detecção da amostra ${ }^{56}$. 
Quadro 2 - Características das matrizes biológicas sangue, fluido oral, urina e cabelo na identificação de droga de abuso.

\begin{tabular}{|c|c|c|c|c|}
\hline & Sangue & Fluido Oral & Urina & Cabelo \\
\hline Tempo de detecção & 1-2 dias & $1-2$ dias & $3-4$ dias & $\begin{array}{c}3-6 \\
\text { meses }\end{array}$ \\
\hline Coleta invasiva & Sim & Não & Sim & Sim \\
\hline Possibilidade de adulteração & Não & Baixa & Alta & Média \\
\hline Contaminação externa & Não & Não & Não & Sim \\
\hline Taxa de recusa & Alta & Baixa & Média & Alta \\
\hline $\begin{array}{l}\text { Possibilidade de resultado } \\
\text { negativo após uso da droga }\end{array}$ & Baixa & Baixa & Baixa & Alta \\
\hline Custo da análise & Médio & Médio & Médio & Alto \\
\hline
\end{tabular}

Fonte: adaptado de Gjerde, 2011.

\subsection{Uso de fluido oral para fiscalização no trânsito}

Atualmente, 159 países possuem legislação proibindo 0 uso de substâncias psicoativas por condutores de veículos automotores. Entretanto a maioria desses países não especifica quais substâncias são realmente proibidas $^{32}$.

No Brasil, o Código de Trânsito Brasileiro, em seu artigo 165, estabelece a proibição da condução veicular sob efeito de álcool e outras substâncias que causem dependência ${ }^{57}$. Entretanto, não especifica quais substâncias são realmente proibidas e também maneiras de se avaliar a presença da droga.

Por outro lado, alguns países, principalmente na Europa, já possuem definidas as substâncias ilegais e seus respectivos limites legais, o que viabiliza a coleta de matrizes biológicas com a finalidade de realizar análises toxicológicas ${ }^{58,59}$. 
Alguns países da União Europeia possuem leis que permitem a coleta de fluido oral para detecção de drogas psicoativas em motoristas. A Bélgica foi um dos primeiros países a implementar, em 2009, a coleta e triagem de drogas em fluido oral, com posterior confirmação em amostras de sangue em casos positivos $^{60}$. Já na Espanha, a legislação obriga um motorista parado em blitz, ou envolvido em acidentes de trânsito, a fornecer uma amostra de fluido oral para análises. Nesse caso, um teste preliminar é realizado no local da coleta. Caso o resultado seja positivo, uma outra amostra de fluido oral é coletada e enviada a um laboratório para confirmação, tendo o motorista o direito de solicitar a análise em uma amostra de sangue para confirmação61. De maneira semelhante, a Austrália também permite a coleta e triagem de amostras de fluido oral no local de abordagem do motorista ${ }^{62}$.

Em 2012, a Noruega aprovou uma lei definindo limites de deteç̧ão para 20 substâncias dentre medicamentos e drogas ilícitas. Amostras de fluido oral podem ser coletadas para triagem e a confirmação ocorre por análise sanguínea ${ }^{58}$.

Apesar de a utilização do fluido oral para detecção de substâncias em condutores estar aumentando ao redor do mundo, ainda são necessários estudos e melhorias em dispositivos de testes rápidos. Os dispositivos presentes no mercado não apresentam valores de sensibilidade e especificidade adequados para algumas substâncias, podendo inclusive apresentar falsospositivos devido à reação cruzada com outras substâncias ou alimentos ${ }^{63,64,65}$.

Já foram apresentados resultados satisfatórios de sensibilidade e especificidade para testes rápidos para detecção de cocaína em fluido oral. Entretanto, testes foram realizados em locais controlados, onde os participantes eram monitorados ${ }^{66}$. Quando a avaliação dos dispositivos foi realizada no local da coleta das amostras, vários problemas foram relatados, como alteração do resultado influenciado pela temperatura no local ${ }^{67}$. 


\subsection{Microextração em fase sólida}

Uma análise toxicológica quali e quantitativa confiável é a base para um julgamento competente no âmbito da toxicologia forense. A determinação de analitos-alvo não pode ser realizada sem um pré-tratamento das amostras, que muitas vezes são compostas de matrizes complexas e particuladas ${ }^{68}$. O prétratamento tem como objetivo remover interferentes que possam impossibilitar a identificação do analito e até mesmo adsorver da coluna analítica ou danificar o equipamento. Além disso também é responsável por isolar, extrair e concentrar o analito-alvo. A fase de preparação da amostra possui grande influência em uma análise exata e confiável, consumindo cerca de $80 \%$ do tempo de toda a análise e sendo responsável por até $30 \%$ dos erros analíticos ${ }^{69}$.

As formas de extração mais tradicionais empregadas são a extração líquido-líquido e a extração em fase sólida. Ambas são complexas, com várias etapas, demoradas e requerem uma grande quantidade de amostra e solventes orgânicos ${ }^{70}$. Atualmente 0 apelo ambiental tem ganhado força em diversas áreas, incluindo as análises toxicológicas. Em vista desse novo cenário novas formas de extração começaram a surgir, com o princípio de miniaturizar os métodos existentes. Nos anos 1990, foi descrito pela primeira vez o uso da microextração em fase sólida (SPME) ${ }^{71}$. Ao contrário das extrações tradicionais, a SPME diminui drasticamente e em alguns casos elimina completamente a utilização de qualquer tipo de solvente, combina todas as etapas em uma única, tornando-se mais rápida, simples, menor custo, além de possibilitar o acoplamento a sistemas cromatográficos, automatizando a técnica ${ }^{72}$.

Atualmente existem diversos métodos de se realizar SPME: extração por imersão da fibra, headspace SPME, in vivo e SPME capilar ${ }^{73}$. Os métodos mais empregados nas análises toxicológicas são a imersão direta da fibra e 0 headspace SPME.

SPME por imersão direta da fibra na amostra a extração é realizada pela adsorção dos analitos de interesse na fibra até que o equilíbrio entre a fase estacionária e a amostra seja atingido. Para essa técnica, as fibras utilizadas são 
revestidas por diversas substâncias de acordo com 0 analito alvo. $O$ revestimento da fibra é o fator determinante da seletividade e eficiência da extração, e a natureza química do analito-alvo determina o tipo de revestimento a ser empregado. Para a extração de analitos apolares o revestimento mais comumente empregado é o polidimetilsiloxano (PDMS), já para analitos polares, o poliacrilato ${ }^{69}$.

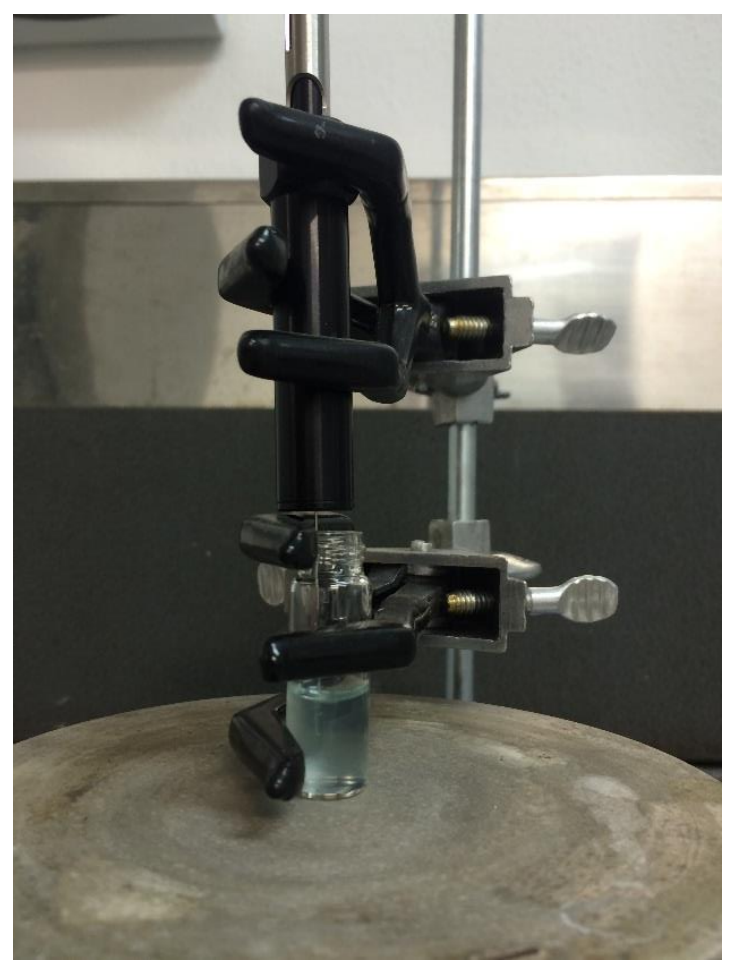

Figura 6. Microextração em fase sólida por imersão direta da fibra

SPME é considerada uma técnica não exaustiva, pois uma pequena parte do analito-alvo é removida da matriz, não esgotando a amostra e causando alterações mínimas no sistema em análise. Além disso, é uma técnica muito flexível, possibilitando sua aplicação em diversas áreas, como análises ambientais, alimentícias, desenvolvimento e monitoramento de fármacos e acompanhamento de linhagens celulares ${ }^{74}$. 
OBJETIVOS 


\section{Objetivos}

O objetivo do presente estudo foi avaliar a frequência do uso de substâncias psicoativas (anfetamina, maconha e cocaína) entre motoristas profissionais de caminhão que trafegam nas rodovias do estado de São Paulo através de análise em fluido oral. Além disso, visamos correlacionar os resultados das análises toxicológicas com dados sociodemográficos e ocupacionais obtidos na aplicação de questionários estruturados.

Para obtenção dos objetivos, o seguinte plano de trabalho foi seguido:

1) Realização de pesquisa bibliográfica;

2) Coleta de amostras de fluido oral de motoristas que participaram dos Comandos de Saúde nas Rodovias (CSR), bem como de dados socioeconômicos através de aplicação de questionários;

3) Triagem das amostras de fluido oral para as substâncias de interesse, pela técnica de ELISA;

4) Validação dos métodos de confirmação por cromatografia gasosa acoplada à espectrometria de massas (GC-MS);

5) Confirmação dos resultados nas amostras de fluido oral positivas no teste de triagem para as substâncias de interesse (anfetamina, $\triangle 9$-THC e cocaína) por GC-MS;

6) Avaliação dos resultados obtidos.

7) Publicação dos dados obtidos. 


\section{MATERLAIS E MÉTODOS}




\section{Materiais e Métodos}

\subsection{Materiais}

\subsubsection{Equipamentos}

- Cromatógrafo gasoso, modelo GC 2010, equipado com coluna capilar HP 5MS (Hewlett Packard) com as seguintes dimensões: $30 \mathrm{~m} \times 0,25 \mathrm{~mm} \times$

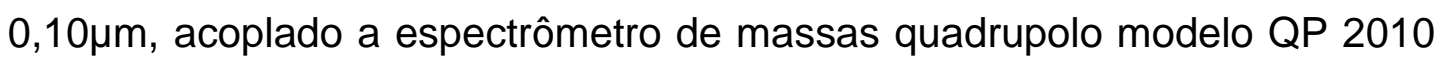
ambos da Shimadzu®, Japão.

- Espectrofotômetro - Leitor de microplaca SpectraMax® M2/M2, da Molecular Devices, EUA.

- Agitador magnético 752 A - Fisatom, São Paulo, Brasil.

\subsubsection{Reagentes e outros materiais}

O reagente derivatizante, butilcloroformato, foi adquirido da Sigma-Aldrich (St.Louis, EUA). Bicarbonato de sódio e carbonato de potássio, metanol e acetonitrila foram adquiridos da Merck (Darmstadt, Alemanha).

Os seguintes padrões de referência para as análises toxicológicas foram adquiridos da Cerilliant (Texas, EUA):

- Cocaína;

- Anfetamina;

- $\triangle 9$-THC;

- Cocaína-D3;

- Anfetamina-D5;

- $\Delta 9$-THC-D3.

Os dispositivos de coleta de fluido oral, Quantisal ${ }^{\mathrm{TM}}$, e os kits de ELISA para a etapa de triagem, assim como o tampão de extração do dispositivo de coleta, foram adquiridos da Immunalysis (Pomona, Califórnia, EUA) 
As fibras para microextração em fase sólida de PDMS (Polidimetilsiloxano) $100 \mu \mathrm{m}$ foram adquiridas da Sigma-Aldrich (St.Louis, EUA).

Vidrarias especiais e outros itens para as análises cromatográficas foram adquiridos de empresas especializadas existentes no mercado brasileiro.

Gases especiais para cromatografia foram obtidos da Air Liquide, Brasil

\subsubsection{Amostras negativas}

Amostras de fluido oral de referência negativa foram obtidas de voluntários que não utilizaram nenhuma das substâncias a serem pesquisadas, cocaína, anfetamina ou maconha. O fluido oral foi diluído no tampão próprio do dispositivo Quantisal ${ }^{\mathrm{TM}}$ (1:4) para reproduzir a mesma condição de coleta.

\subsubsection{Amostras positivas}

As amostras de referência positiva foram obtidas adicionando-se os padrões analíticos de cocaína, anfetamina e $\triangle 9$-THC às amostras negativas. Estas amostras de fluido oral foram utilizadas na validação dos métodos de confirmação.

\subsection{Métodos}

\subsubsection{Comandos de Saúde nas Rodovias}

Desde 2008, o grupo de pesquisa Álcool, drogas e trânsito, do Departamento de Medicina Legal, Ética Médica e Medicina Social e do Trabalho da FMUSP, vem trabalhando com policiais da Policia Rodoviária Federal (PRF), no programa de prevenção à saúde do caminhoneiro, denominado Comandos de Saúde nas Rodovias (CSR). Os CSR são eventos organizados pela PRF em parceria com o Serviço Social do Transporte e Serviço Nacional de 
Aprendizagem no Trânsito (SEST e SENAT). Ocorrem quatro vezes ao ano, em rodovias federais, em dias e locais definidos pela PRF, simultaneamente em todos em estados do Brasil e Distrito Federal. São eventos de promoção à saúde dos motoristas de caminhão com objetivo de identificar fatores de risco à saúde e evitar a ocorrência de AT.

Os motoristas participantes são submetidos à aferição de pressão arterial, exames bioquímicos de glicemia, medidas antropométricas, exame de acuidade visual, auditiva e força manual. Após todos os exames clínicos, recebem orientação médica.

\subsubsection{Casuística}

Para o presente estudo foram utilizados dados sociodemográficos e amostras de fluido oral de motoristas de caminhão que trafegavam em diferentes rodovias do estado de São Paulo, participantes nos CSR. Foram analisadas e incluídas no estudo 762 amostras coletadas em 5 dias de CSR (Quadro 3). Todas as coletas ocorreram às quartas-feiras, das 9 horas às 16 horas.

Quadro 3 - Datas, locais e quantidade de amostras de fluido oral coletadas de motoristas de caminhão em cada dia de CSR.

\begin{tabular}{cccc}
\hline \multicolumn{1}{c}{ Data } & Município & Rodovia & $\begin{array}{c}\text { Amostras } \\
\text { coletadas }\end{array}$ \\
\hline $19 / 03 / 2014$ & Atibaia & Fernão Dias (BR 381) & 150 \\
$07 / 05 / 2014$ & São José do Rio Preto & Transbrasiliana (BR & 169 \\
$29 / 10 / 2014$ & Itapecerica da Serra & Régis Bittencourt (BR & 135 \\
& & $116)$ & 141 \\
$26 / 11 / 2014$ & Cachoeira Paulista & Presidente Dutra (BR & 140 \\
$11 / 03 / 2015$ & & $116)$ & 167 \\
\hline Total & Atibaia & Fernão Dias (BR 381) & 162 \\
\hline
\end{tabular}




\subsubsection{Abordagem dos motoristas}

Os motoristas de caminhão foram abordados por policiais rodoviários federais, que os convidavam a participar do CSR, de acordo com o espaço disponível para estacionar os caminhões, constituindo, desta maneira, uma amostra de conveniência.

Após o término de todas as atividades incluídas no CSR, os motoristas eram convidados a participar do estudo, respondendo a um questionário estruturado e doando uma amostra de fluido oral.

\subsubsection{Critério de inclusão e exclusão}

Foram incluídos no estudo todos os motoristas de caminhão que após esclarecimento sobre o projeto, leitura e assinatura do termo de consentimento livre e esclarecido (TCLE) (Anexo A), aceitaram responder o questionário e doaram amostras de fluido oral. Foram excluídos aqueles que se recusaram a participar.

\subsubsection{Aplicação do questionário}

Foi aplicado aos participantes um questionário estruturado para coletar informações como idade, grau de escolaridade, estado civil, tempo de serviço como motorista de caminhão e do trajeto total a ser percorrido durante a viagem, bem como, relatos sobre o consumo de drogas (Anexo B). 


\subsubsection{Coleta de amostras de fluido oral}

As amostras foram coletadas através do dispositivo Quantisal ${ }^{\mathrm{TM}}$ (Figura 7), que consiste em uma haste com material absorvente na ponta, inserida na boca do participante, para absorção do fluido oral. Posteriormente, a haste é submergida em tampão próprio do dispositivo para armazenamento e conservação da amostra. Os dispositivos foram previamente identificados com um número de controle laboratorial, sem qualquer identificação do participante. As amostras foram mantidas sob refrigeração, em geladeiras térmicas e conduzidas ao laboratório no mesmo dia da coleta e armazenadas em freezer ($20^{\circ} \mathrm{C}$ ), sendo descongeladas à temperatura ambiente à medida em que eram procedidas as análises.

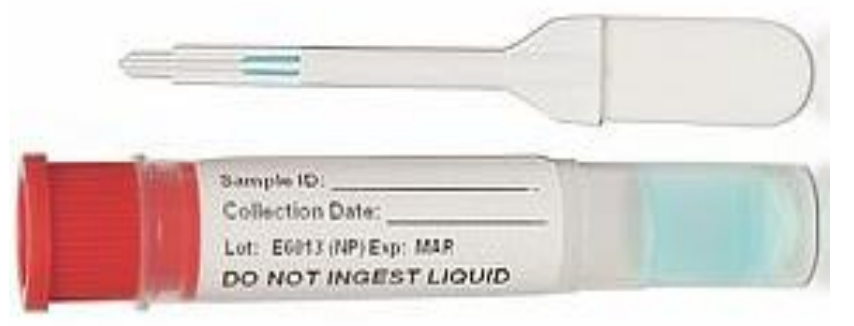

Figura 7. Dispositivo de coleta de fluido oral, Quantisal ${ }^{\mathrm{TM}}$.

\subsubsection{Aspectos Éticos}

O estudo foi aprovado pelo Comitê de Ética em Pesquisa da FMUSP; Protocolo № 135/14 (Anexo C). 


\subsubsection{Análises toxicológicas}

\subsubsection{Análises de triagem}

As amostras de fluido oral foram submetidas a ensaios imunoenzimáticos (ELISA - Enzyme-Linked Immunosorbent Assay). Os ensaios foram realizados em microplacas de 96 poços, contendo anticorpos específicos para cada tipo de droga. Cada amostra foi submetida a três ensaios, um para cocaína, um para anfetamina e outro para $\triangle 9$-THC. A técnica de ELISA utilizada foi do tipo competitivo, no qual a concentração da droga na amostra é inversamente proporcional à absorbância obtida. Este procedimento é apenas qualitativo, portanto todas as amostras que apresentaram uma absorbância abaixo daquela apresentada pelo cut-off, foram consideradas positivas. O cut-off utilizado para cada substância foi: $20 \mathrm{ng} / \mathrm{mL}$ para cocaína, $50 \mathrm{ng} / \mathrm{mL}$ para anfetaminas e $4 \mathrm{ng} / \mathrm{mL}$ para $\triangle 9$-THC. Todos os procedimentos foram realizados seguindo manual do kit adquirido, bem como todos os reagentes utilizados nesta etapa.

\subsubsection{Análises de confirmação}

Os analitos de interesse foram extraídos das amostras de fluido oral utilizando a técnica de SPME, utilizando fibra de PDMS- $100 \mu \mathrm{m}^{75}$, de acordo com o seguinte procedimento:

A um frasco de $4 \mathrm{~mL}$ foi adicionado $2 \mathrm{~mL}$ de fluido oral, $200 \mathrm{mg}$ de $\mathrm{NaHCO}_{3} / \mathrm{K}_{2} \mathrm{CO}_{3}$ (2:1) e $10 \mathrm{ng} / \mathrm{mL}$ dos padrões internos (cocaína-d3 e $\Delta-9 \mathrm{THC}$ ) e $25 \mathrm{ng} / \mathrm{mL}$ de anfetamina-d5. A solução foi agitada por 20 minutos, em temperatura ambiente, com a fibra de PDMS submergida na solução. No método de extração para anfetamina a derivatização do analito foi realizada na própria solução durante o período de extração, adicionando-se $2 \mu \mathrm{L}$ de butilcloroformato.

Após o período de extração, a fibra de PDMS foi introduzida no injetor do cromatógrafo gasoso, permanecendo durante todo o período de separação 
cromatográfica, para limpeza total da fibra, diminuindo o risco de contaminação da próxima amostra a ser analisada.

Durante o desenvolvimento de nosso estudo, foi celebrada uma parceria entre nosso grupo de pesquisa e pesquisadores do Instituto Norueguês de Saúde Pública (NIPH). Assim sendo, tivemos a oportunidade de enviar uma alíquota das amostras consideradas positivas na etapa de triagem ao NIPH para análises não só das substâncias de interesse para o nosso estudo, bem como para a investigação de outras substâncias que no momento não seria possível a identificação em nosso laboratório. No NIPH as amostras foram analisadas por métodos que envolvem a técnica de cromatografia líquida de ultra eficiência acoplada à espectrometria de massas em tandem (UPLC-MS/MS). Na rotina de análise do NIPH estão incluídas 32 substâncias, dentre drogas ilícitas e medicamentos psicotrópicos ${ }^{76}$.

O cut-off utilizado no NIPH para cada substância foi: $10 \mathrm{ng} / \mathrm{mL}$ para cocaína, $25 \mathrm{ng} / \mathrm{mL}$ para anfetamina e $1 \mathrm{ng} / \mathrm{mL}$ para $\Delta 9-\mathrm{THC}$.

\subsubsection{Validação dos métodos de confirmação}

Os métodos de confirmação para a cocaína, $\triangle 9$-THC e anfetamina foram validados estabelecendo-se valores de limite de detecção, limite de quantificação, precisão, exatidão, linearidade, carryover, integridade da diluição e estabilidade. Todos os parâmetros foram avaliados seguindo recomendações de manuais internacionais de validação de métodos ${ }^{77,78}$.

\subsubsection{Condições cromatográficas}

Todas as injeções foram realizadas manualmente no GC-MS. Para a identificação dos analitos utilizou-se o método full scan. Uma vez identificados o 
tempo de retenção e o espectro de massas, o método SIM foi utilizado para a quantificação das substâncias.

Para a análise de cocaína as seguintes condições cromatográficas foram estabelecidas.

A temperatura do injetor foi mantida em $250^{\circ} \mathrm{C}$. A temperatura do forno e a rampa de aquecimento está demonstrada no Quadro 5. O gás de arraste utilizado foi o hélio em um fluxo de $0,6 \mathrm{~mL} / \mathrm{min}$. A temperatura da interface entre o cromatógrafo e o espectrômetro de massas foi mantida em $250^{\circ} \mathrm{C}$ e a da fonte de íons em $220^{\circ} \mathrm{C}$. O detector foi operado por ionização eletrônica em $70 \mathrm{eV}$ no método SIM.

Quadro 4 - Condições de elevação e controle de temperatura no cromatógrafo gasoso para o método de detecção da cocaína.

$\begin{array}{ccc}\text { Taxa de aumento da } & \text { Temperatura } & \text { Permanência em minutos } \\ \text { temperatura }\left({ }^{\circ} \mathrm{C} / \mathrm{min}\right) & \text { final }\left({ }^{\circ} \mathrm{C}\right) & \text { na temperatura final }\end{array}$

\begin{tabular}{lll}
\hline & 150 & 2 \\
15 & 220 & 0 \\
20 & 250 & 5 \\
\hline
\end{tabular}

Tempo total de separação cromatográfica: 13,17min

Os íons analisados foram: cocaína: 182, 272, 303; cocaína-d3: 185, 275 e 306. Os fragmentos sublinhados foram os utilizados na quantificação.

Para a análise do $\triangle 9-\mathrm{THC}$ a temperatura do injetor foi mantida em $280^{\circ} \mathrm{C}$, a temperatura do forno e a rampa de aquecimento está demonstrada no Quadro 6. A temperatura da interface foi mantida em $250^{\circ} \mathrm{C}$ e da fonte de íons em $220^{\circ} \mathrm{C}$. O detector também foi operado em $70 \mathrm{eV}$ no método SIM. 
Quadro 5 - Condições de elevação e controle de temperatura no cromatógrafo gasoso para o método de deteç̧ão de $\triangle 9$-THC.

$\begin{array}{ccc}\text { Taxa de aumento da } & \text { Temperatura } & \begin{array}{c}\text { Permanência em minutos } \\ \text { temperatura }\left({ }^{\circ} \mathrm{C} / \mathrm{min}\right)\end{array} \\ \text { final }\left({ }^{\circ} \mathrm{C}\right) & \text { na temperatura final }\end{array}$

\begin{tabular}{ccc}
\hline \multirow{2}{*}{15} & 150 & 2 \\
& 250 & 8 \\
\hline
\end{tabular}

Tempo total de separação cromatográfica: $16,67 \mathrm{~min}$

Os íons analisados foram: $\Delta 9$-THC: $231, \underline{299}, 314 ; \Delta 9$-THC-d3: $234, \underline{302}$, 317. Os fragmentos sublinhados foram os utilizados na quantificação.

Para a análise da anfetamina a temperatura do injetor foi mantida em $250^{\circ} \mathrm{C}$, a temperatura do forno e a rampa de aquecimento está demonstrada no Quadro 7. A temperatura da interface foi mantida em $250^{\circ} \mathrm{C}$ e da fonte de íons em $220^{\circ} \mathrm{C}$. O detector também foi operado em $70 \mathrm{eV}$ no método SIM.

Quadro 6 - Condições de elevação e controle de temperatura no cromatógrafo gasoso para o método de detecção de anfetamina.

$\begin{array}{ccc}\text { Taxa de aumento da } & \begin{array}{c}\text { Temperatura } \\ \text { temperatura }\left({ }^{\circ} \mathrm{C} / \mathrm{min}\right)\end{array} & \begin{array}{c}\text { Permanência em minutos } \\ \text { final }\left({ }^{\circ} \mathrm{C}\right)\end{array} \\ \text { na temperatura final }\end{array}$

\begin{tabular}{lll}
\hline & 120 & 1 \\
10 & 220 & 0 \\
15 & 250 & 2 \\
\hline
\end{tabular}

Tempo total de separação cromatográfica: $15 \mathrm{~min}$

\subsubsection{Limite de detecção e quantificação}

Limite de detecção (LOD) é definido como a menor concentração que pode ser diferenciada, de forma confiável, do ruído de uma amostra branca (sem adição de qualquer padrão). Limite de quantificação (LOQ) é definido como a menor concentração que pode ser quantificada, de forma confiável, mantendose valores aceitáveis de precisão e exatidão ${ }^{77,79,80}$. 
Inicialmente foi determinado o limite do branco (LOB), através de uma série de injeções de amostras sem adição de qualquer padrão. Foram analisadas 20 replicatas para se estimar a linha de base de detecção do aparelho.

Após a determinação do LOB, o limite de detecção foi estimado realizando uma série de injeções com concentrações decrescentes (15; 10; 8; 6; 5; 4; 3,5; $3 ; 2,5 ; 2 \mathrm{ng} / \mathrm{mL}$ ). Seis replicatas de cada concentração foram analisadas e aquela que apresentou um sinal três vezes maior que o LOB foi considerado LOD.

Para a determinação do limite de quantificação foi realizado o mesmo procedimento do LOD. A menor concentração que apresentou um coeficiente de variação menor que $10 \%$ foi estimado como sendo o LOQ.

\subsubsection{Precisão intra e interdias}

Os estudos de precisão foram realizados analisando uma série de amostras de fluido oral adicionadas com padrão de cocaína. Foram usados três controles: controle de qualidade baixo (CQB), controle de qualidade médio (CQM) e controle de qualidade alto (CQA), os valores de cada um dos controles para cada analitos estão apresentados no Quadro 7.

Quadro 7 - Concentrações dos controles de qualidade baixo (CQB), médio (CQM) e alto (CQA) para a validação dos métodos de confirmação para cocaína, anfetamina e $\triangle 9$-THC.

\begin{tabular}{cccc}
\hline & CQB $(\mathbf{n g} / \mathbf{m L})$ & CQM $(\mathbf{n g} / \mathbf{m L})$ & CQA $(\mathbf{n g} / \mathbf{m L})$ \\
\hline Cocaína & 12 & 60 & 120 \\
Anfetamina & 10 & 80 & 150 \\
$\Delta$ 9-THC & 15 & 60 & 120 \\
\hline
\end{tabular}

As análises foram realizadas em três dias consecutivos e em seis replicatas para cada controle. Foi determinada a precisão intradia e interdia, determinando-se indiretamente a imprecisão do método pelo cálculo do coeficiente de variação $(\mathrm{CV})$, sendo o valor máximo aceitável $10 \%$.

As fórmulas utilizadas nos cálculos foram: 
Precisão intradias $=\left(\frac{(\sqrt{\text { Média dentro dos grupos }})}{\text { Média geral }}\right) \times 100$

Precisão interdias $=\left(\frac{\frac{\sqrt{\text { Média entre grupos }+(\mathrm{n}-1) \mathrm{X} \text { Média dentro dos grupos }}}{\mathrm{n}}}{\text { Média geral }}\right) \times 100$

\subsubsection{Exatidão}

Exatidão é definida como a concordância entre a média de resultados encontrados experimentalmente e o valor real de uma amostra. Foi determinada analisando-se os controles CQB, CQM e CQA em seis replicatas, sendo que o valor máximo aceitável é $\pm 20 \%$.

A fórmula utilizada nos cálculos foi:

$$
\text { Inexatidão }(\%)=\left(\frac{\text { concentração obtida }- \text { concentração real }}{\text { concentração real }}\right) \times 100
$$

\subsubsection{Linearidade}

O estudo da linearidade foi realizado analisando amostras de fluido oral nas seguintes concentrações para os métodos de detecção de cocaína e $\Delta 9$ THC: 5, 25, 50, 75, 100, 125 e $150 \mathrm{ng} / \mathrm{mL}$. Já para o método de detecção de anfetamina as concentrações da curva de calibração foram as seguintes: 5 , 35, 70, 100, 140, 175 e 200ng/mL. Cada concentração foi analisada em cinco replicatas. Uma curva de calibração foi montada e o coeficiente de correlação calculado. A heteroscedasticidade da curva de calibração foi analisada ${ }^{81}$. 


\subsubsection{Carryover}

Este fenômeno é determinado analisando uma amostra branca logo após uma amostra com alta concentração do analito de interesse. Nenhuma concentração acima do LOD pode ser verificada na amostra branca.

Foi determinado analisando-se uma amostra com concentração de $500 \mathrm{ng} / \mathrm{mL}$ dos analitos e logo em seguida uma amostra branca. Análise foi realizada em triplicata.

\subsubsection{Estabilidade}

O estudo de estabilidade dos analitos foi realizado mantendo amostras de fluido oral, adicionados com concentrações dos analitos referentes ao CQB, CQM e CQA, em temperatura ambiente $22^{\circ} \mathrm{C}$, geladeira $\left(4^{\circ} \mathrm{C}\right)$ e freezer $\left(-20^{\circ} \mathrm{C}\right)$. Cada amostra de cada ambiente foi analisada em três dias diferentes e consecutivos.

A estabilidade foi analisada comparando-se a concentração obtida no tempo zero com as concentrações obtidas após o tempo do armazenamento (24, 48 e 72h). Cada concentração em cada condição de armazenamento foi analisada em triplicata.

\subsubsection{Integridade da diluição}

A integridade da diluição deve ser verificada toda vez que a amostra precisa ser diluída por apresentar concentrações do analito superiores àquelas estipuladas no método ou quando apresentar volume insuficiente para análise. Com o estudo deste parâmetro é possível assegurar que a precisão e a exatidão do método não serão afetadas com a diluição da amostra.

As análises foram realizadas repetindo os estudos de precisão e exatidão com amostras diluídas (1:2, 1:4, 1:10). As amostras foram diluídas utilizando 
fluido oral sem adição dos analitos de interesse. Foi utilizada amostra de fluido oral adicionada com $250 \mathrm{ng} / \mathrm{mL}$ de cocaína, $\Delta 9-\mathrm{THC}$ e anfetamina. Cada diluição foi analisada em triplicata em três dias consecutivos.

\subsubsection{Análises estatísticas}

Os dados obtidos por meio de aplicação dos questionários, bem como os resultados das análises toxicológicas foram analisados utilizando o software STATA 13 (StataCorp LP, College Station, Texas). Foi realizada uma análise descritiva das variáveis e aplicada testes de regressão Tobit e Probit para verificar a associação entre os dados. 
RESULTADOS 
5. Resultados

\subsection{Validação do método de confirmação}

\subsubsection{Limite de deteção e quantificação}

Os limites de detecção e quantificação para cada analito estão apresentados no Quadro 8.

Quadro 8 - Valores de limite de detecção e limite de quantificação para os métodos de confirmação para cocaína, anfetamina e $\Delta 9-T H C$.

\begin{tabular}{ccc}
\hline & LOD & LOQ \\
\hline Cocaína & $4 \mathrm{ng} / \mathrm{mL}$ & $4 \mathrm{ng} / \mathrm{mL}$ \\
Anfetamina & $3 \mathrm{ng} / \mathrm{mL}$ & $5 \mathrm{ng} / \mathrm{mL}$ \\
$\Delta$ 9-THC & $4 \mathrm{ng} / \mathrm{mL}$ & $4 \mathrm{ng} / \mathrm{mL}$ \\
\hline
\end{tabular}




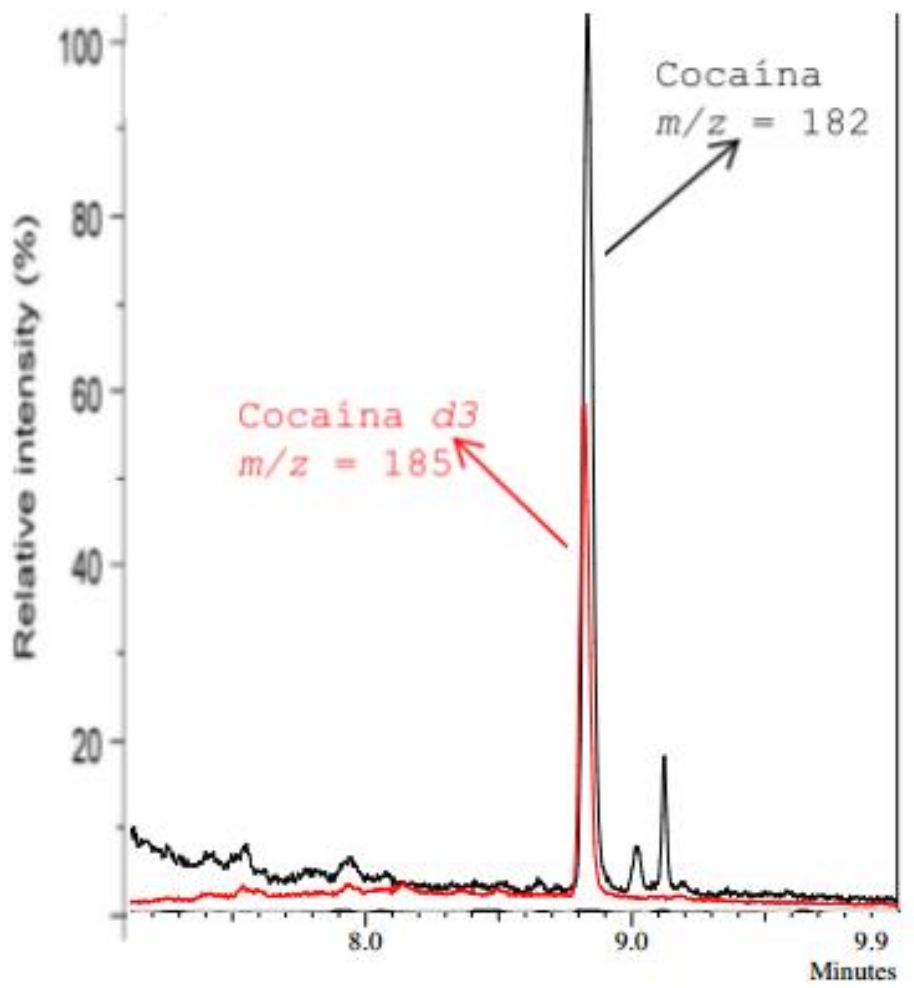

Figura 8. Cromatograma referente à amostra adicionada com $500 \mathrm{ng} / \mathrm{mL}$ de padrão de cocaína e cocaína-D3.

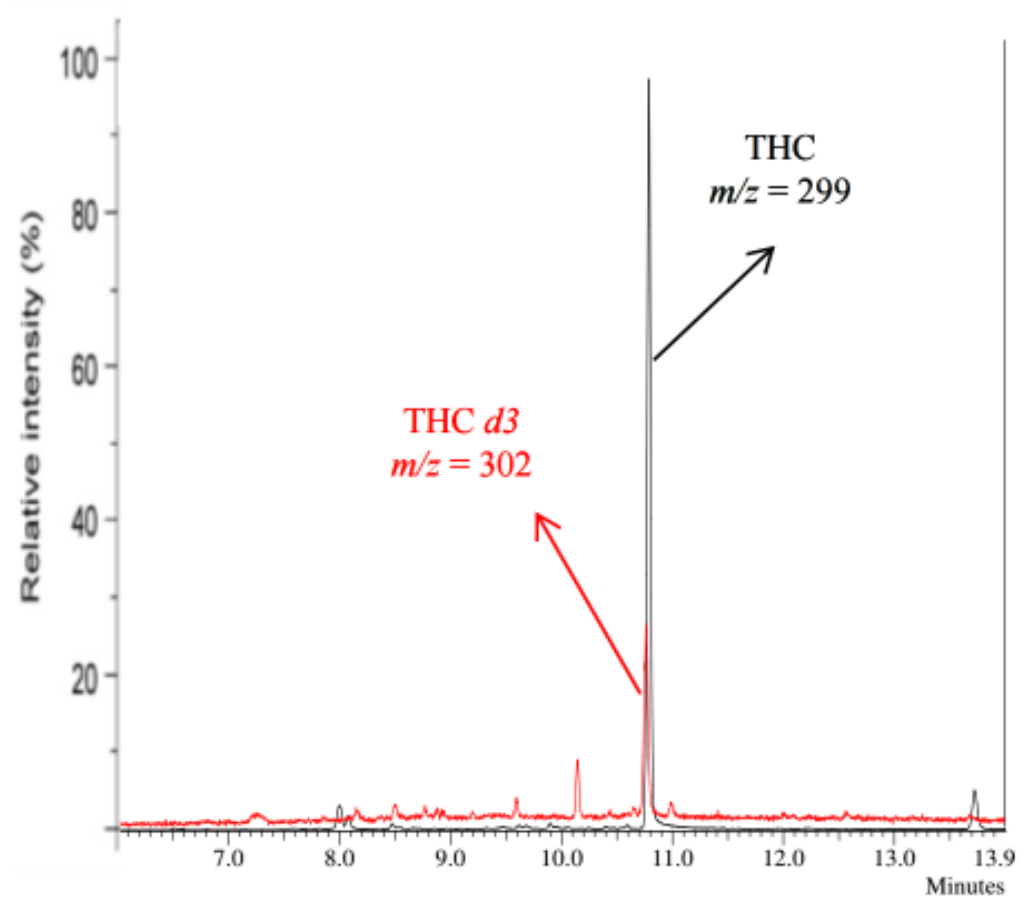

Figura 9. Cromatograma referente à amostra adicionada com $500 \mathrm{ng} / \mathrm{mL}$ de padrão de $\Delta 9$-THC e $\Delta 9$-THC -D3. 


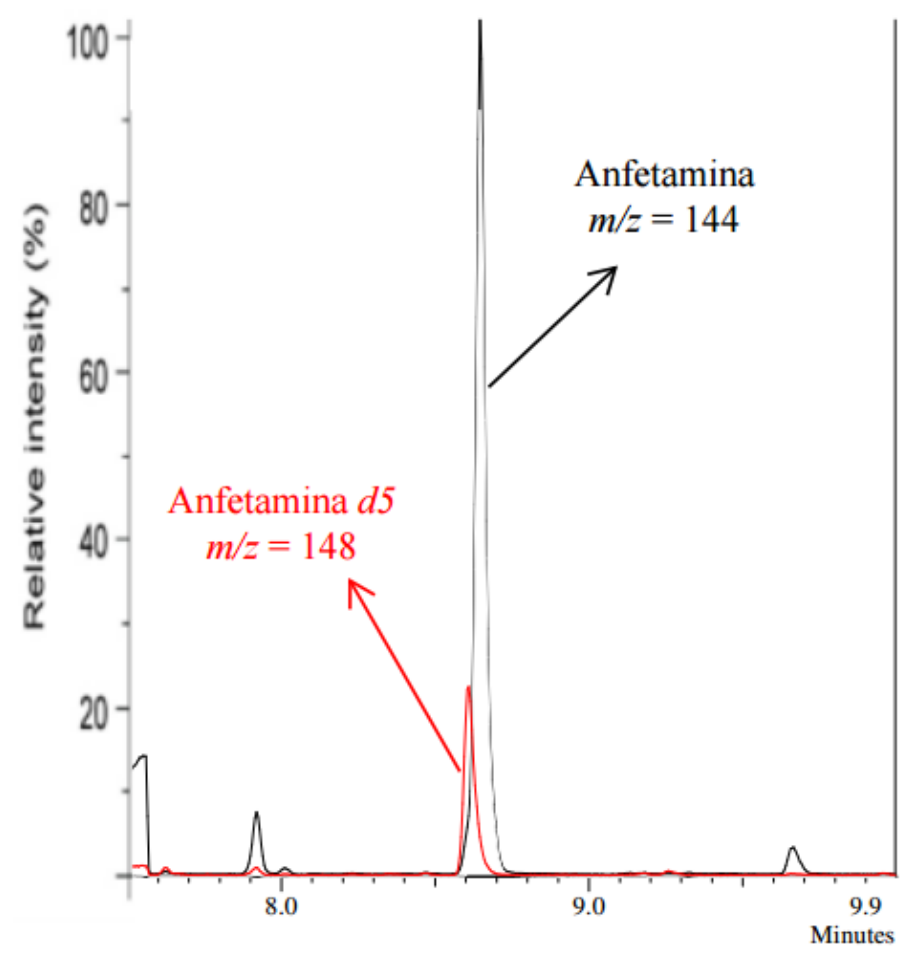

Figura 10. Cromatograma referente à amostra adicionada com 500ng/mL de padrão de anfetamina e anfetamina-D5.

\subsubsection{Precisão intra e interdias}

As precisões intra e interdias foram determinadas em três concentrações diferentes: CQB, CQM e CQA. Os valores dos CVs obtidos estão apresentados na Tabela 1.

\subsubsection{Exatidão}

A exatidão foi avaliada utilizando-se as análises realizadas nos estudos de precisão. A partir das médias de todas das as injeções para cada controle, a inexatidão do método foi calculada. Nas Tabelas 1, 2 e 3 estão demonstrados os valores da inexatidão de cada controle utilizado. 
Tabela 1 - CV intradia e interdia e exatidão obtidos nas três concentrações estudadas para cocaína.

\begin{tabular}{cccc}
\hline & $\mathbf{1 2 n} \mathbf{g} / \mathbf{m L}$ & $\mathbf{6 0} \mathbf{n g} / \mathbf{m L}$ & $\mathbf{1 2 0} \mathbf{n g} / \mathbf{m L}$ \\
\hline CV intradia & $7,7 \%$ & $3 \%$ & $4,5 \%$ \\
CV interdia & $8,1 \%$ & $3,4 \%$ & $4,4 \%$ \\
Exatidão & $-11,3 \%$ & $-18,6 \%$ & $-5,8 \%$
\end{tabular}

Tabela 2 - CV intradia e interdia e exatidão obtidos nas três concentrações estudadas para $\triangle 9-\mathrm{THC}$.

\begin{tabular}{cccc}
\hline & $\mathbf{1 5 n \mathbf { n }} / \mathbf{m L}$ & $\mathbf{6 0 n g} / \mathbf{m L}$ & $\mathbf{1 2 0} \mathbf{n g} \mathbf{m L}$ \\
\hline CV intradia & $7 \%$ & $9,8 \%$ & $4,1 \%$ \\
CV interdia & $3,7 \%$ & $6,5 \%$ & $7,5 \%$ \\
Exatidão & $-10,2 \%$ & $3,1 \%$ & $9,6 \%$ \\
\hline
\end{tabular}

Tabela 3 - CV intradia e interdia e exatidão obtidos nas três concentrações estudadas para anfetamina.

$10 \mathrm{ng} / \mathrm{mL} \quad 80 \mathrm{ng} / \mathrm{mL} \quad 150 \mathrm{ng} / \mathrm{mL}$

\begin{tabular}{cccc}
\hline CV intradia & $9,7 \%$ & $0,7 \%$ & $0,9 \%$ \\
CV interdia & $3,9 \%$ & $1,4 \%$ & $1,8 \%$ \\
Exatidão & $5,3 \%$ & $-2,9 \%$ & $7,1 \%$ \\
\hline
\end{tabular}

\subsubsection{Linearidade e Heteroscedasticidade}

Os dados da linearidade dos três métodos, bem como os coeficientes de correlação e a faixa de concentração estudadas estão ilustrados na Tabela 4. 
Tabela 4 - Faixas de concentração, equação obtida, coeficiente de correlação (R2), estudo de heteroscedeasticidade e fator de ponderação utilizados na validação dos métodos de confirmação para cocaína, $\triangle 9-\mathrm{THC}$ e anfetamina.

\section{Cocaína $\quad \Delta$-THC Anfetamina}

\begin{tabular}{cccc}
\hline $\begin{array}{c}\text { Faixa de } \\
\text { concentração }\end{array}$ & $\begin{array}{c}4 \mathrm{ng} / \mathrm{mL} \text { a } \\
150 \mathrm{ng} / \mathrm{mL}\end{array}$ & $\begin{array}{c}5 \mathrm{ng} / \mathrm{mL} \text { a } \\
150 \mathrm{ng} / \mathrm{mL}\end{array}$ & $\begin{array}{c}5 \mathrm{ng} / \mathrm{mL} \text { a } \\
200 \mathrm{ng} / \mathrm{mL}\end{array}$ \\
$\begin{array}{c}\text { Equação } \\
\mathbf{R}^{2}\end{array}$ & $\begin{array}{c}\mathrm{Y}=0,11625 \mathrm{x} \\
0,0803\end{array}$ & $\mathrm{Y}=0,118 \mathrm{x}-0,21$ & $\mathrm{Y}=0,083 \mathrm{x}-0,034$ \\
Heteroscedasticidade & $\mathrm{Sim}$ & $\mathrm{Sim}$ & $\mathrm{Sim}$ \\
Fator de ponderação & $\frac{1}{x^{2}}$ & $\frac{1}{x^{2}}$ & $\frac{1}{x^{2}}$ \\
\hline
\end{tabular}

\subsubsection{Carryover}

Com a análise de uma amostra branca após injeção de uma amostra contendo $500 \mathrm{ng} / \mathrm{mL}$ de cada analito, utilizando-se a mesma fibra de PDMS, foi possível constatar que os três métodos não apresentaram arraste dos analitos de uma amostra para a posterior, sendo o tempo de exposição da fibra ao injetor do GC-MS suficiente para promover sua limpeza.

\subsubsection{Estabilidade}

Amostras de fluido oral, adicionadas com $60 \mathrm{ng} / \mathrm{mL}$ dos analitos a serem detectados, cocaína, $\triangle 9$-THC e anfetamina, foram armazenadas em três ambientes: $22^{\circ} \mathrm{C}, 4^{\circ} \mathrm{C}$ e $-20^{\circ} \mathrm{C}$, durante 24,48 e 72 horas. A análise da estabilidade foi realizada para os três controles: CQB, CQM e CQA. Cada amostra, em cada condição de armazenamento, foi analisada em triplicata. Foi 
calculada a porcentagem de variação para cada concentração em cada ambiente de armazenamento. Todas as concentrações apresentaram uma variação menor que $\pm 10 \%$, o que reflete uma alteração não significativa na concentração do analito ao longo de três dias em diferentes ambientes de armazenamento (Tabela 5, 6 e 7).

Tabela 5 - Variação (\%) de cada concentração de cocaína, em cada ambiente de armazenamento.

\begin{tabular}{|c|c|c|c|c|c|c|c|c|c|}
\hline & \multicolumn{3}{|c|}{ CQB } & \multicolumn{3}{|c|}{ CQM } & \multicolumn{3}{|c|}{ CQA } \\
\hline & $24 \mathrm{~h}$ & $48 \mathrm{~h}$ & $72 h$ & $24 \mathrm{~h}$ & $48 \mathrm{~h}$ & $72 h$ & $24 \mathrm{~h}$ & $48 \mathrm{~h}$ & $72 h$ \\
\hline $22^{\circ} \mathrm{C}$ & 6,02 & 6,57 & $-8,43$ & $-2,11$ & $-5,57$ & $-8,08$ & $-0,9$ & 0,37 & $-3,7$ \\
\hline $4 \div \mathrm{C}$ & 4,38 & $-0,32$ & $-7,66$ & 8,51 & 9,86 & 4,06 & $-7,9$ & $-3,4$ & -5 \\
\hline$-20^{\circ} \mathrm{C}$ & 1,2 & $-2,73$ & $-9,2$ & 8,35 & $-0,1$ & 1,03 & $-8,04$ & -9 & $-7,07$ \\
\hline
\end{tabular}

Controle de qualidade baixo $(\mathrm{CQB})=12 \mathrm{ng} / \mathrm{mL}$; Controle de qualidade médio $(C Q M)=60 \mathrm{ng} / \mathrm{mL}$; Controle de qualidade alto $(C Q A)=120 \mathrm{ng} / \mathrm{mL}$

Tabela 6 - Variação (\%) de cada concentração de $\Delta 9$-THC, em cada ambiente de armazenamento durante três dias consecutivos.

\begin{tabular}{cccccccccc}
\hline \multicolumn{3}{c}{ CQB } & \multicolumn{3}{c}{ CQM } & \multicolumn{3}{c}{ CQA } \\
\hline & $\mathbf{2 4 h}$ & $\mathbf{4 8 h}$ & $\mathbf{7 2 h}$ & $\mathbf{2 4 h}$ & $\mathbf{4 8 h}$ & $\mathbf{7 2 h}$ & $\mathbf{2 4 h}$ & $\mathbf{4 8 h}$ & $\mathbf{7 2 h}$ \\
\hline $\mathbf{2 2}-\mathbf{C}$ & $-4,9$ & 0 & $-4,9$ & $-8,5$ & $-9,2$ & $-6,8$ & $-7,6$ & $-7,7$ & 6,1 \\
$\mathbf{4}^{\circ} \mathbf{C}$ & $-8,5$ & 2,4 & 4,9 & $-7,8$ & $-7,3$ & $-3,9$ & $-6,7$ & 7,9 & 6,9 \\
$\mathbf{- 2 0} \mathbf{C}$ & $-8,5$ & 1,2 & 9,8 & $-7,8$ & $-5,8$ & $-0,2$ & $-9,6$ & $-6,8$ & $-6,9$ \\
\hline
\end{tabular}

Controle de qualidade baixo $(\mathrm{CQB})=15 \mathrm{ng} / \mathrm{mL}$; Controle de qualidade médio $(C Q M)=60 \mathrm{ng} / \mathrm{mL} ;$ Controle de qualidade alto $(C Q A)=120 \mathrm{ng} / \mathrm{mL}$

Tabela 7 - Variação (\%) de cada concentração de anfetamina, em cada ambiente de armazenamento durante três dias consecutivos.

\begin{tabular}{cccccccccc}
\hline & \multicolumn{3}{c}{ CQB } & \multicolumn{3}{c}{ CQM } & \multicolumn{3}{c}{ CQA } \\
\hline & $\mathbf{2 4 h}$ & $\mathbf{4 8 h}$ & $\mathbf{7 2 h}$ & $\mathbf{2 4 h}$ & $\mathbf{4 8 h}$ & $\mathbf{7 2 h}$ & $\mathbf{2 4 h}$ & $\mathbf{4 8 h}$ & $\mathbf{7 2 h}$ \\
\hline $\mathbf{2 2}^{\circ} \mathbf{C}$ & 3,8 & 1,7 & $-4,9$ & 1,1 & $-5,3$ & 5,7 & 3,6 & $-2,7$ & 1,5 \\
$\mathbf{4}^{\circ} \mathbf{C}$ & 2,3 & 6,8 & $-2,4$ & 5,4 & 2,7 & 1,2 & 4,7 & 4,6 & 7,3 \\
$\mathbf{- 2 0}^{\circ} \mathbf{C}$ & $-5,1$ & 0,6 & 5,5 & 3,6 & 3,4 & 8,1 & $-3,2$ & $-5,4$ & 2,8
\end{tabular}

Controle de qualidade baixo $(\mathrm{CQB})=10 \mathrm{ng} / \mathrm{mL}$; Controle de qualidade médio $(C Q M)=80 \mathrm{ng} / \mathrm{mL}$; Controle de qualidade alto $(C Q A)=150 \mathrm{ng} / \mathrm{mL}$ 


\subsubsection{Integridade da diluição}

A uma amostra de fluido oral foi adicionado $250 \mathrm{ng} / \mathrm{mL}$ de cocaína, a outra também 250ng/mL de $\Delta 9-\mathrm{THC}$ e a uma terceira amostra, $300 \mathrm{ng} / \mathrm{mL}$ de anfetamina. Essas amostras foram diluídas em três proporções 1:2, 1:4 e 1:10 utilizando fluido oral livre dos analitos analisados. Essas amostras foram analisadas em triplicata e em três dias diferentes e consecutivos.

Os testes de precisão intradia e interdia foram aplicados aos resultados obtidos. Com os coeficientes de variação encontrados foi possível observar que apesar das diluições realizadas, o método continuou preciso. A exatidão também foi avaliada e não houve resultados maiores que $\pm 15 \%$ (Tabelas 8,9 e 10).

Tabela 8 - Coeficientes de variação e exatidão para as três diluições realizadas em uma amostra de fluido oral contendo $250 \mathrm{ng} / \mathrm{mL}$ de cocaína.

$1: 2 \quad 1: 4$

\begin{tabular}{cccc}
\hline CV intradia & $3,9 \%$ & $4,9 \%$ & $2,3 \%$ \\
CV interdia & $5,5 \%$ & $4,0 \%$ & $2,6 \%$ \\
Exatidão & $-7,9 \%$ & $-7,7 \%$ & $11,3 \%$ \\
\hline
\end{tabular}

Tabela 9 - Coeficientes de variação e exatidão para as três diluições realizadas em uma amostra de fluido oral contendo $250 \mathrm{ng} / \mathrm{mL}$ de $\Delta 9-\mathrm{THC}$.

$1: 2 \quad 1: 4 \quad 1: 10$

\begin{tabular}{cccc}
\hline CV intradia & $5,7 \%$ & $5,2 \%$ & $4,3 \%$ \\
CV interdia & $4,8 \%$ & $9 \%$ & $8,8 \%$ \\
Exatidão & $8,4 \%$ & $5,3 \%$ & $-3,2 \%$
\end{tabular}


Tabela 10 - Coeficientes de variação e exatidão para as três diluições realizadas em uma amostra de fluido oral contendo $300 \mathrm{ng} / \mathrm{mL}$ de anfetamina.

$\begin{array}{lll}1: 2 & 1: 4 & 1: 10\end{array}$

\begin{tabular}{cccc}
\hline CV intradia & $1,2 \%$ & $1,9 \%$ & $4 \%$ \\
CV interdia & $2 \%$ & $3,7 \%$ & $5,2 \%$ \\
Exatidão & $-1,9 \%$ & $2,5 \%$ & $-6,2 \%$ \\
\hline
\end{tabular}

\subsection{Perfil dos motoristas incluídos}

Durante os cinco dias de coleta realizados, foram abordados 764 motoristas de caminhão. Destes, apenas dois $(0,2 \%)$ se recusaram a participar e a doar amostras de fluido oral, alegando falta de tempo para participar.

Todos os participantes são homens, com média estimada de idade de 42,5 anos. A maioria deles (71,7\%) é casado ou em situação marital (amasiado) e estudou até a $8^{\text {a }}$ série (41\%). Com relação às atividades laborais, 67,7\% mantinham algum vínculo empregatício, com uma média estimada de tempo de 15,6 anos de trabalho como motorista de caminhão. Os participantes dirigiam uma média estimada de 9,4 horas por dia e o percurso médio estimado era de 614 quilômetros.

\subsection{Análise de triagem}

Após as análises de triagem, 6,2\% $(n=48)$ das amostras apresentaram resultado positivo para algum tipo de droga. Cocaína foi a droga mais presente $(2,6 \%)$, seguida da anfetamina $(2,1 \%)$ e $\Delta 9$-THC $(0,9 \%)$. Cinco amostras apresentaram positividade para mais de uma classe de substâncias, sendo duas 
amostras para cocaína e anfetamina, outras duas para cocaína e THC e uma amostra positiva para anfetamina e THC (Tabela 11).

Tabela 11 - Quantidade de amostras positivas para cada substância analisada nas análises de triagem em amostras de fluido oral de motoristas de caminhão $(\mathrm{n}=48)$ no estado de São Paulo.

\begin{tabular}{ccc}
\hline Substância & № de amostras positivas & $\%$ \\
\hline Cocaína & 20 & 2,6 \\
Anfetamina & 16 & 2,1 \\
$\Delta 9-\mathrm{THC}$ & 7 & 0,9 \\
Cocaína $+\Delta 9-\mathrm{THC}$ & 2 & 0,2 \\
Cocaína + Anfetamina & 2 & 0,2 \\
Anfetamina $+\Delta 9-\mathrm{THC}$ & 1 & 0,1
\end{tabular}

\subsection{Análise de confirmação}

Após as análises confirmatórias, 5,2\% $(n=40)$ das amostras apresentaram resultados positivos para uma ou mais substâncias (Tabela 12). A cocaína foi a substância mais identificada, seguida da anfetamina e $\Delta 9$-THC (Figura 11). Com o envio das amostras de fluido oral para o NIPH foi possível a identificação de outras duas substâncias que não seriam pesquisadas em nosso laboratório, o alprazolam e o meprobamato. 
Tabela 12 - Amostras de fluido oral, coletadas de motoristas de caminhão que trafegavam em rodovias do estado de São Paulo, positivas na análise de confirmação por GC/MS e UPLC-MS/MS ( $n=40)$.

\begin{tabular}{ccc}
\hline Substância & № de amostras & $\%$ \\
\hline Cocaína & 16 & 2 \\
Anfetamina & 11 & 1,4 \\
$\Delta 9$-THC & 4 & 0,5 \\
Cocaína + $\Delta 9$-THC & 3 & 0,4 \\
Cocaína + Anfetamina & 1 & 0,1 \\
Anfetamina + $\Delta$ 9-THC & 1 & 0,1 \\
Anfetamina + Alprazolam & 1 & 0,1 \\
Anfetamina + Meprobamato & 2 & 0,2 \\
Cocaína + Meprobamato & 1 & 0,1
\end{tabular}

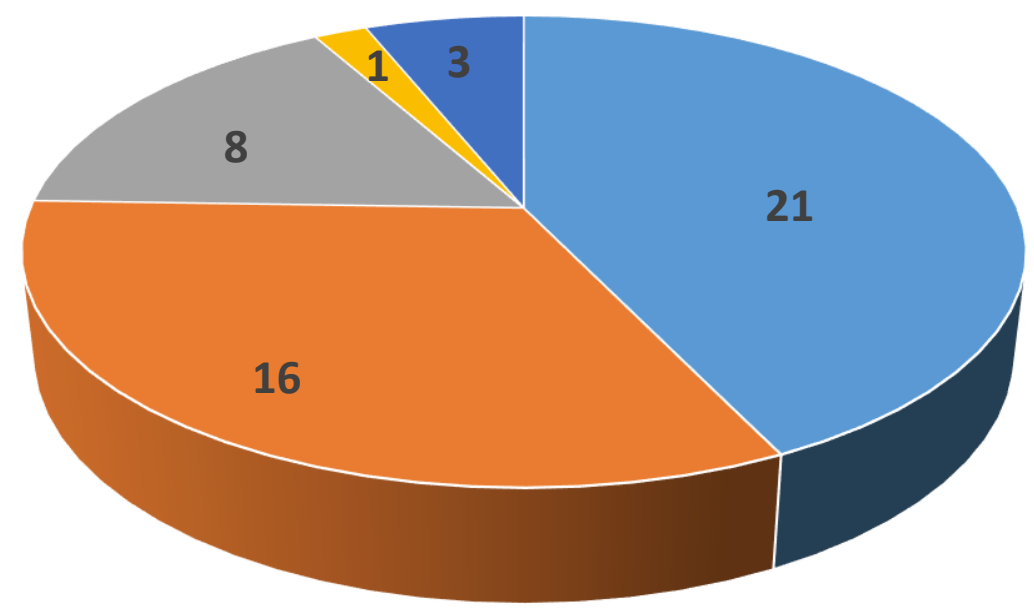

- Cocaína $\backsim$ Anfetamina $\backsim \Delta 9-\mathrm{THC} \backsim$ Alprazolam $\backsim$ Meprobamato

Figura 11. Número de identificações de cada uma das 5 substâncias encontradas nas amostras de fluido oral nas análises confirmatórias por UPLC-MS/MS. 


\subsection{Perfil dos motoristas com amostras positivas}

Os motoristas que apresentaram amostras de fluido oral com resultados positivos tinham 36,9 anos em média, 52,5\% eram casados ou amasiados e $62,5 \%$ estudaram até a $8^{\text {a }}$ série. Com relação às atividades laborais, 52,5\%\% mantinham algum vínculo empregatício, com uma média de tempo de 13,2 anos de trabalho como motorista de caminhão. Os participantes dirigiam uma média de 10,5 horas por dia e o percurso médio era de 1100 quilômetros na viagem. $A$ diferença entre os perfis de todos os motoristas incluídos no estudo e aqueles que apresentaram resultados positivos nas análises toxicológicas está apresentado na Tabela 13.

Tabela 13 - Distribuição das características sociodemográficas e ocupacionais de motoristas de caminhão abordados em rodovias do estado de São Paulo com amostras de fluido oral positivas $(n=40)$ e com amostras negativas $(n=722)$.

\begin{tabular}{|c|c|c|c|}
\hline Variável & $\begin{array}{c}\text { Motoristas com } \\
\text { amostras } \\
\text { negativas }\end{array}$ & IC 95\% & $\begin{array}{l}\text { Motoristas com } \\
\text { amostras } \\
\text { positivas }\end{array}$ \\
\hline
\end{tabular}

\begin{tabular}{|c|c|c|c|c|}
\hline Média de idade & 42,8 anos & $\pm 0,7$ & 36,9 anos & $\pm 11,4$ \\
\hline $\begin{array}{c}\text { Estado civil } \\
\text { Solteiro/divorciado } \\
\text { Casado/amasiado }\end{array}$ & $\begin{array}{l}25 \% \\
75 \%\end{array}$ & & $\begin{array}{l}47,5 \% \\
52,5 \%\end{array}$ & \\
\hline $\begin{array}{l}\text { Escolaridade } \\
\quad \leq 8 \text { anos } \\
>8 \text { anos }\end{array}$ & $\begin{array}{l}53 \% \\
47 \%\end{array}$ & & $\begin{array}{l}62,5 \% \\
37,5 \%\end{array}$ & \\
\hline $\begin{array}{c}\text { Tipo de serviço } \\
\text { Autônomo } \\
\text { Contratado }\end{array}$ & $\begin{array}{l}30,3 \% \\
69,7 \%\end{array}$ & & $\begin{array}{l}52,5 \% \\
47,5 \%\end{array}$ & \\
\hline $\begin{array}{c}\text { Tempo de } \\
\text { profissão (média) }\end{array}$ & 15,8 anos & $\pm 0,8$ & 13,2 anos & \pm 4 \\
\hline $\begin{array}{l}\text { Jornada diária } \\
\quad \leq 10 \mathrm{~h} / \text { dia } \\
>10 \mathrm{~h} / \mathrm{dia}\end{array}$ & $\begin{array}{c}9,3 \mathrm{~h} \text { (média) } \\
63,7 \% \\
36,6 \%\end{array}$ & $\pm 0,2$ & $\begin{array}{c}10,5 \mathrm{~h} \text { (média) } \\
60 \% \\
40 \%\end{array}$ & $\pm 10,4$ \\
\hline $\begin{array}{c}\text { Percurso da } \\
\text { viagem } \\
\leq 500 \mathrm{~km} \\
>500 \mathrm{~km}\end{array}$ & $\begin{array}{c}586 \mathrm{Km} \text { (média) } \\
66,3 \% \\
33,7 \%\end{array}$ & $\pm 54,5$ & $\begin{array}{c}1100 \text { Km (média) } \\
\\
42,5 \% \\
57,5 \%\end{array}$ & $\pm 325,5$ \\
\hline Total & 722 & & 40 & \\
\hline
\end{tabular}




\subsection{Comparação entre percurso e uso de substâncias psicoativas}

Os motoristas que relataram o consumo de álcool apresentaram uma média de percurso relativamente maior do que aqueles que relataram não consumirem, $646,6 \mathrm{Km}$ e $570,5 \mathrm{Km}$ respectivamente. Ao avaliar a média de percurso dos motoristas que apresentaram amostras de fluido oral para anfetamina, cocaína e $\triangle 9$-THC, também foi possível observar uma diferença entre a média de percurso realizada por eles. No caso do $\triangle 9$-THC aqueles que apresentaram um percurso médio maior $(615,1 \mathrm{Km})$, apresentaram resultados negativos nas análises toxicológicas. Para as substâncias estimulantes, anfetamina e cocaína, os motoristas com amostras positivas apresentaram percurso médio maior, 1738,7 Km contra 589, $5 \mathrm{Km}$ para anfetaminas e 701,9 Km contra 611,5 Km para cocaína (Figura 12).

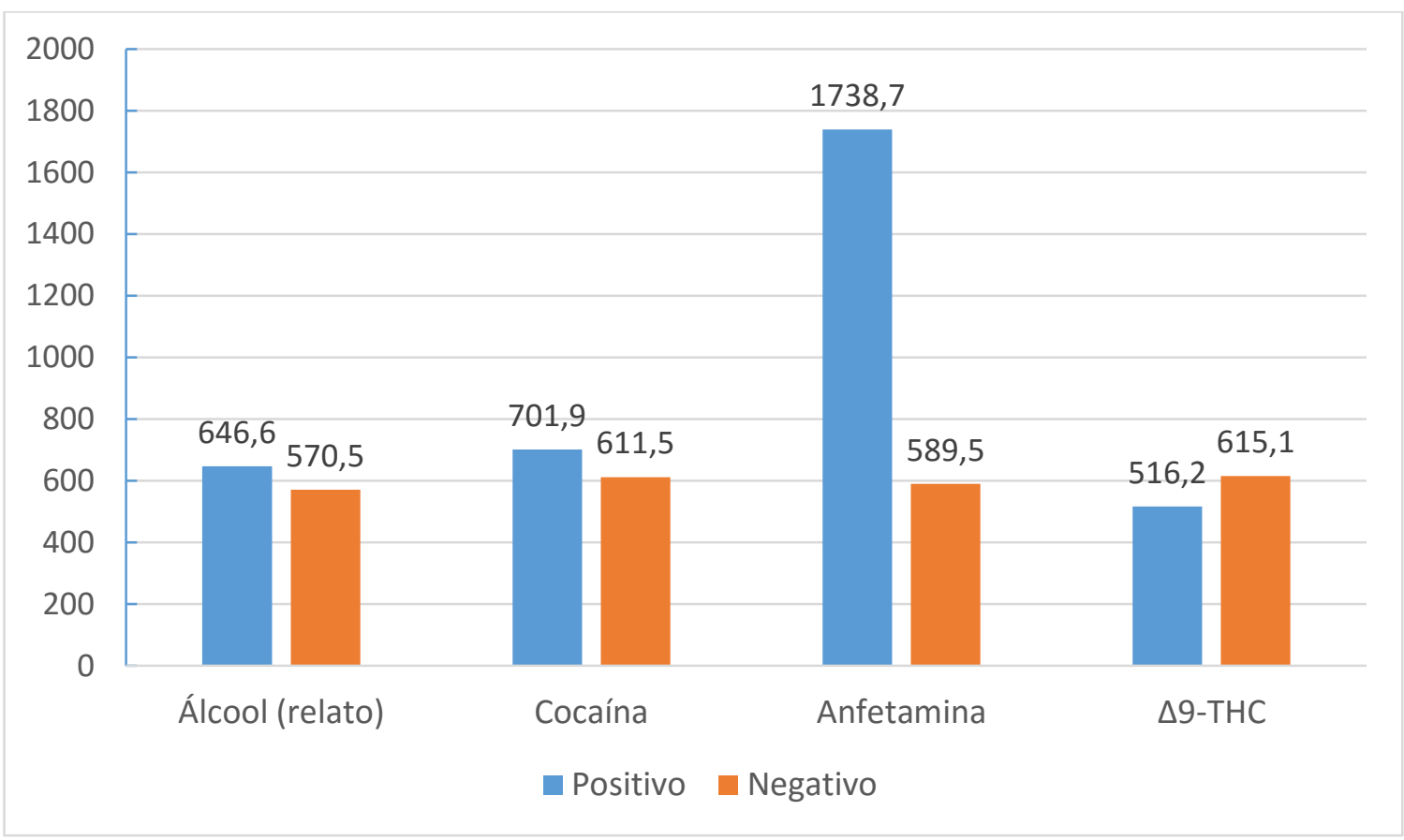

Figura 12. Comparação entre a média de percurso entre aqueles que relataram o uso e não de álcool e entre os motoristas que apresentaram resultados positivos e negativos para anfetamina, cocaína e $\Delta 9$-THC. 
Ao avaliar os resultados das análises toxicológicas com o percurso, também foi possível identificar que aqueles motoristas que percorrem um percurso mais longo apresentaram uma maior porcentagem de amostras positivas para anfetaminas. O mesmo não é observado para a cocaína e $\Delta 9$ THC, que apresentaram um padrão de uso homogêneo dentre os caminhoneiros quando comparado à distância percorrida (Figura 13), sendo que usuários de maconha não percorriam mais de $1500 \mathrm{Km}$.

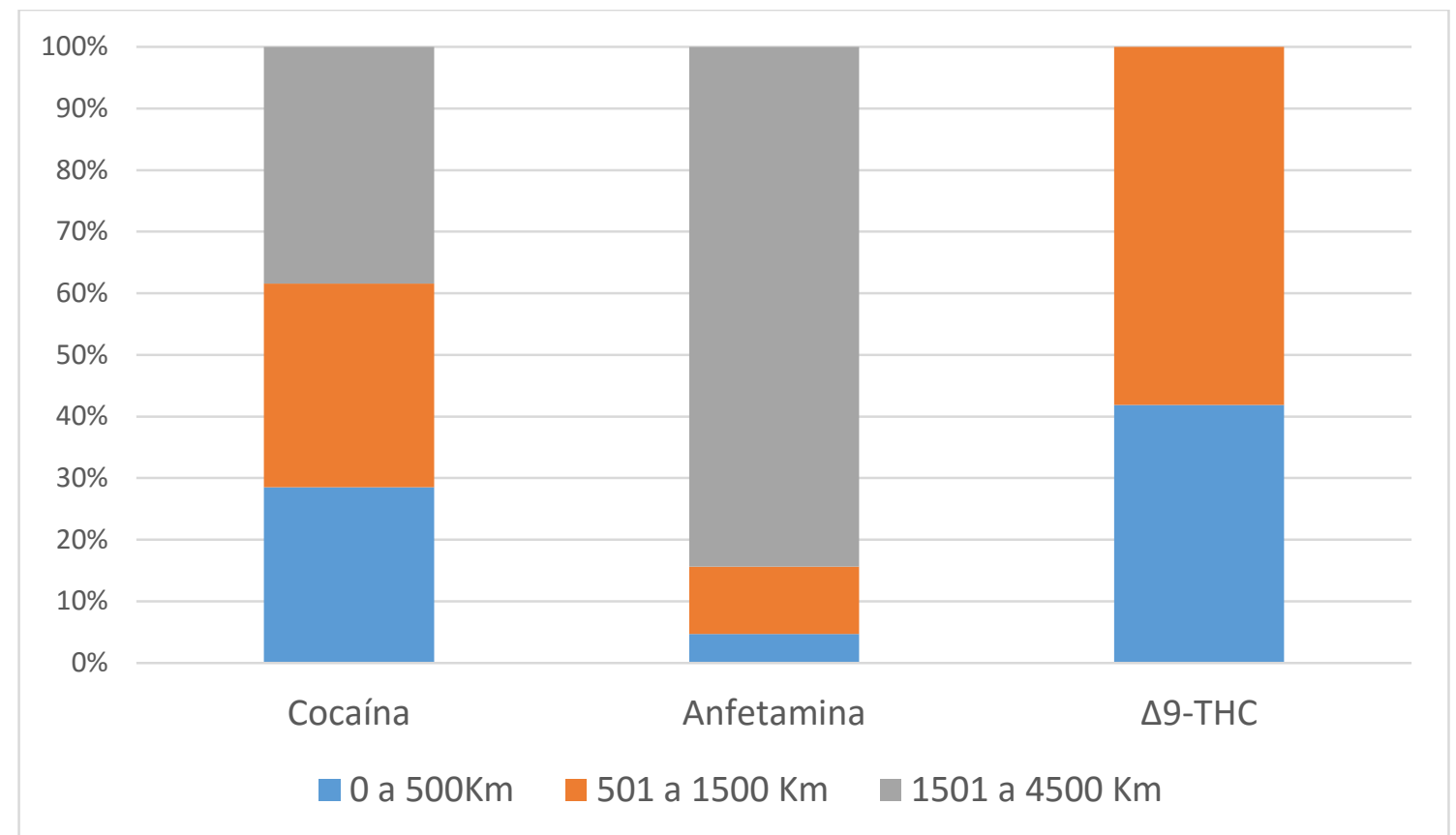

Figura 13. Distribuição da porcentagem de amostras positivas de acordo com percurso percorrido, estratificado em 3 níveis: de 0 a $500 \mathrm{Km}$, de 501 a $1500 \mathrm{Km}$ e de 1501 a $4500 \mathrm{Km}$.

\subsection{Probabilidade de envolvimento em acidentes de trânsito}

Foi observado uma correlação estatisticamente significativa entre o envolvimento prévio em acidentes de trânsito com o nível de escolaridade, o percurso realizado pelo motorista e a duração da jornada diária de trabalho. A probabilidade de o motorista já ter se envolvido em AT decresce conforme o nível de escolaridade aumenta, sendo a probabilidade de envolvimento em AT 0,022 menor a cada estágio de educação concluído $(p=0,027)$. Em relação à distância que o motorista percorre a probabilidade de envolvimento em acidente aumenta, 
sendo 0,043 maior a cada $100 \mathrm{~km}$ percorridos $(p=0,036)$. O mesmo ocorre para a jornada diária de trabalho, a cada uma hora trabalhada a probabilidade de AT aumenta em $0.019(p=0,00)$.

\subsection{Relatos do uso de drogas}

Dos 40 motoristas que apresentaram resultados positivos para alguma substância, apenas 21 (52,5\%) relataram já ter utilizado cocaína ou maconha, sendo que apenas 3 destes afirmaram ter utilizado a substância na semana anterior à coleta. Em relação ao consumo de anfetamina, 25 (62,5\%) motoristas afirmaram o uso, sendo apenas 6 na semana anterior à coleta. No Quadro 9 estão especificados cada relato para cada substância pesquisada.

Quadro 92 - Número de participantes que relataram o uso das substâncias pesquisadas na semana, mês ou ano anterior às coletas e há mais de um ano da coleta, dentre aqueles que apresentaram resultados positivos para alguma substância nas análises confirmatórias ( $n=40)$.

\begin{tabular}{ccccc}
\hline Substância & \multicolumn{5}{c}{ Relato do uso } \\
\cline { 2 - 5 } & $\leq 7$ dias & $\leq 1$ mês & $\leq 1$ ano & $>1$ ano \\
\hline Cocaína & 1 & 2 & 4 & 4 \\
Anfetamina & 6 & 2 & 5 & 12 \\
$\Delta$ 9-THC & 2 & 0 & 6 & 4 \\
\hline
\end{tabular}




\section{DISCUSSÃO}




\section{Discussão}

Em vista dos números alarmantes que os AT atingiram, medidas precisaram ser implantadas visando diminuir os impactos negativos gerados pelos acidentes. Diante disso, a ONU, em 2010, decretou a década de 2011 a 2020 como a "Década de Ação pela Segurança no Trânsito" com o objetivo de diminuir pela metade o número de AT e com isso salvar milhares de vidas ${ }^{1}$.

No Brasil, medidas também foram implementadas com a intenção de se obter alguma redução na mortalidade relacionada com os AT. Em 2010, foi implementado o projeto "Projeto Vida no Trânsito", integrando a iniciativa internacional "Road Safety in Ten Countries" (RS10). Contando com a parceria de diversas instituições, como: OMS, Association for Safe International Road Travel, Johns Hopikins Bloomberg School of Public Health, World Bank Global Road Safety Facility e Bloomberg Philanthropies, dez países, incluíndo o Brasil, foram convidados a participar por apresentarem, juntos, 600 mil mortes por AT por ano. Projeto esse que apresentou como objetivo a diminuição dos AT e melhoria na segurança viária ${ }^{82}$.

Em 2015, ocorreu em Brasília, a Segunda Conferência Global de Alto Nível sobre Segurança no Trânsito, com o objetivo de apresentar resultados das ações implementadas desde 2010, no Brasil e no mundo, e sugerir ações para fortalecer o gerenciamento da segurança no trânsito. Dentre as ações propostas estão a identificação de fatores que alterem ou diminuam a capacidade do condutor, como medicamentos, drogas narcóticas e substâncias psicoativas ${ }^{83}$. Estas ações refletem a preocupação do Brasil frente aos óbitos decorrentes de AT e reforça a importância de atingir as metas propostas pela OMS com a "Década de Ação pela Segurança no Trânsito".

Algumas outras ações poderiam contribuir de maneira indireta para a redução de AT. A ANVISA, através da RDC 50/2014 proibiu a comercialização, prescrição e aviamento de medicamentos contendo anfepramona, femproporex, mazindol e sibutramina ${ }^{25}$. Tais medicamentos eram utilizados como 
moderadores de apetite e emagrecedores. Entretanto, eram consumidos de forma abusiva por motoristas de caminhão devido aos efeitos de suprimir o sono e cansaço. Como consequência da proibição de tais medicamentos e o recorrente problema de pressão por entregas rápidas a que os motoristas de caminhão são submetidos, houve ao longo dos últimos anos uma mudança no perfil de uso de drogas ilícitas. A anfetamina perdeu lugar como estimulante mais utilizado para a cocaína ${ }^{84}$, fato também comprovado por nosso estudo.

Os efeitos deletérios das drogas na condução veicular estão bem descritos na literatura $29,30,31,32$. Apesar disso, substâncias psicotrópicas são frequentemente encontradas em vítimas de AT. Em recente estudo brasileiro, amostras de sangue de 230 motoristas envolvidos em AT foram analisadas para a presença de álcool e drogas ilícitas. Álcool foi encontrado em $25,2 \%$ das amostras e drogas ilícitas em $21,7 \%$, em conjunto com álcool (10,4\%) ou não $(11,3 \%)$. Dentre as drogas, a mais encontrada foi cocaína, presente em 15,1\% das amostras ${ }^{85}$. Entretanto, em nosso estudo, não foi encontrado uma associação significativa entre 0 uso de substâncias psicoativas e 0 acontecimento de AT. Sendo que, de acordo com nossos dados o acontecimento de AT está bastante relacionado com uma baixa escolaridade dos motoristas, uma alta jornada de trabalho e grandes distâncias a serem percorridas.

Apesar de o sangue ser a amostra mais recomendada para se verificar se o motorista está sob efeito da droga no momento da coleta, o fluido oral pode também ser analisado para esse propósito ${ }^{43}$. Diversos dispositivos para coleta de fluido oral estão disponíveis no mercado. Para a escolha do dispositivo ideal é preciso levar em consideração os analitos a serem pesquisados, o local da coleta e o tempo entre a coleta e a análise. No presente estudo foi utilizado o dispositivo Quantisal ${ }^{\mathrm{TM}}$, o qual apresenta uma solução tampão para conservação e estabilização da amostra coletada, o que permite que seja transportada ao laboratório garantindo a estabilidade, evitando perdas das concentrações dos analitos. Esse fato foi comprovado com os testes de estabilidade realizados durante a validação dos métodos confirmatórios. Outra vantagem, é a alta recuperação que apresenta para as substâncias de interesse ${ }^{86,87,88}$. Outro ponto a ser considerado no Quantisal ${ }^{\mathrm{TM}}$ é coleta sem estimulação da salivação. 
Quando a salivação é estimulada durante a coleta pode ocorrer uma mudança do $\mathrm{pH}$ do fluido oral e consequentemente alterar a concentração do analito na amostra $^{43}$.

O presente estudo foi o pioneiro no Brasil na utilização da técnica de ELISA como triagem para amostras de fluido oral na detecção de substâncias psicoativas em motoristas de caminhão. Essa metodologia mostrou-se de fácil realização e interpretação. Os resultados encontrados nessa etapa e depois confirmados pela técnica de UPLC-MS/MS, demonstraram uma alta sensibilidade do teste de ELISA, corroborando achados anteriores na literatura ${ }^{89}$. Outro ponto importante a ser ressaltado é o pequeno volume de amostra necessário para essa técnica. Em cada placa foram utilizados apenas $20 \mu \mathrm{L}$ de amostra. Uma vez que a coleta de fluido oral tem um volume limitado, a quantidade de amostra utilizada nas análises é um ponto importante a ser considerado, sendo essa uma grande vantagem da técnica de ELISA.

Apesar de no fluido oral ser pesquisado a substância inalterada, assim como no sangue, os principais produtos de biotransformação também podem ser encontrados em altas concentrações ${ }^{90}$. Esse fato é importante na verificação de anfetaminas. Como exposto anteriormente, no Brasil as anfetaminas são consumidas na forma de medicamentos moderadores de apetite. Os kits de ELISA que foram utilizados apresentam anticorpos policlonais para $d$ anfetamina. Desta forma, resultados falso-negativos poderiam ser encontrados, uma vez que a triagem não detectaria o uso dos moderadores de apetite utilizados em nosso país, como a anfepramona e femproporex ${ }^{91}$. Apesar disso, já foi comprovado que após a ingestão de femproporex é possível a identificação de anfetamina em amostras de fluido oral após poucos minutos ${ }^{92}$, o que possibilitou a utilização desses kits de ELISA na triagem das amostras.

Em todas as análises toxicológicas é imprescindível a realização de uma análise confirmatória por um método com fundamento diferente daquele utilizado na triagem. A cromatografia acoplada à espectrometria de massas é uma técnica considerada padrão-ouro nas análises toxicológicas. Entretanto, uma grande preocupação com os métodos de extrações dos analitos das amostras é a utilização de grandes quantidades de solventes, prejudiciais ao meio ambiente ${ }^{70}$. 
Com a miniaturização dos métodos o volume de solvente utilizado pôde ser drasticamente diminuído ou, em alguns casos, até mesmo excluído do método ${ }^{93}$. No caso do método de SPME realizado no presente estudo, não houve necessidade de utilização de solventes orgânicos, uma vez que o analito foi extraído diretamente na fibra de PDMS utilizada.

O método de confirmação por GC-MS após SPME mostrou-se de fácil realização e viável na implementação na rotina de laboratórios. Mesmo com a injeção manual realizada nesse estudo, foi possível a análise de mais de 20 amostras em 8 horas de trabalho. Além da facilidade, também podemos ressaltar a não utilização de solventes para a extração, tornando o método mais atrativo em comparação a outros utilizados. Os métodos de confirmação das amostras que foram validados em nosso laboratório mostraram-se dentro dos padrões preconizados pelos manuais internacionais utilizados, apresentando resultados satisfatórios em todos os parâmetros avaliados.

A análise por UPLC-MS/MS, no NIPH permitiu a pesquisa de 32 substâncias simultaneamente em cada amostra, entre medicamentos e drogas ilícitas. Com isso, foram identificadas duas substâncias além da cocaína, anfetamina e $\Delta 9$-THC: alprazolam e meprobamato. Apesar de essas substâncias terem sido pesquisadas apenas nas amostras previamente analisadas na etapa de triagem, esse resultado demonstra que mais estudos devem ser realizados com a finalidade de pesquisar também medicamentos, além das substâncias ilícitas em nosso meio.

O alprazolam é um medicamento benzodiazepínico, depressor do SNC, amplamente utilizado no tratamento de transtornos de ansiedade. O uso desse grupo de medicamentos pode afetar negativamente as funções psicomotoras e cognitivas, importantes na realização de tarefas diárias, incluindo a direção de veículos automotores ${ }^{94,95}$. Os principais efeitos deletérios são: aumento do tempo de reação, diminuição da vigilância e diminuição de memória ${ }^{96}$. Devido a esses efeitos, os usuários de benzodiazepínicos tem de 60 a 80\% mais chance de se envolverem em acidentes de trânsito em comparação aos não usuários ${ }^{94}$. Em nossos resultados o alprazolam foi identificado em amostras juntamente com anfetamina. O uso múltiplo de substâncias pode aumentar ainda mais o risco dos 
condutores se envolverem em $\mathrm{AT}^{97}$. $\mathrm{O}$ uso de duas substâncias com propriedades diferentes pode se dar pelo fato de tentativa de compensação dos efeitos colaterais. Enquanto os benzodiazepínicos causam sonolência, a anfetamina inibe o sono e fadiga, propiciando ao motorista a possibilidade de dirigir por um maior período.

Já o meprobamato pode ter sido detectado após o uso de relaxantes musculares. Essa substância é um dos principais produtos de biotransformação do carisoprodol, presente em vários medicamentos utilizados para alivio de dores $^{98}$. O meprobamato é considerado um depressor do SNC, possuindo atividade semelhante aos benzodiazepínicos ${ }^{99}$. Além da sonolência também pode causar perda de equilíbrio, confusão e aumento no tempo de reação, efeitos que podem comprometer a segura direção veicular ${ }^{100}$. Meprobamato já foi associado com ações perigosas no trânsito como: direção em zigue-zague, alta velocidade, colisão com outros veículo e objetos na pista e condução na direção contrária ao trafego ${ }^{98,101}$. Da mesma maneira ao observado com 0 alprazolam, nas amostras que apresentaram resultados positivos para 0 meprobamato também foram encontradas substâncias estimulantes (cocaína e anfetamina), talvez como uma forma de mascarar os efeitos de sedação produzidos por essas substâncias.

Aqueles motoristas incluídos no presente estudo que apresentaram resultados positivos para alguma substância em suas amostras de fluido oral possuem um perfil diferente do total dos envolvidos. Os motoristas com amostras positivas eram mais jovens, com menos escolaridade, mais inexperientes, possuíam uma jornada de trabalho mais extensa e percorriam percursos mais longos. Todas essas características podem levar a um maior consumo de substâncias ilícitas ${ }^{12,14,15}$. Além disso, a maioria desse grupo trabalhava de forma autônoma, portanto não possuíam qualquer tipo de controle sobre o quanto dirigiam por dia e nem o quanto descansavam. Já foi relatado na literatura a associação entre o uso de drogas ilícitas e um maior trajeto percorrido ${ }^{102}$, o que confirma nossos achados.

Em nossos resultados também foi possível observar que aqueles motoristas que realizam uma viagem com percurso superior a $500 \mathrm{Km}$ tem uma 
tendência maior ao consumo de anfetamina. Entretanto, o uso da cocaína não apresenta o mesmo padrão, sendo distribuída igualmente entre motoristas com trajetos maiores e menores que $500 \mathrm{Km}$. De maneira semelhante, aqueles motoristas, cujas amostras testaram positivo para anfetamina, apresentaram uma média de percurso muito superior $(1738,7 \mathrm{KM})$ do que aqueles, cujas amostras testaram positivo para cocaína $(701,9 \mathrm{Km})$ e $\Delta 9$-THC $(516,25 \mathrm{Km})$. Essa diferença pode estar relacionada com a intenção de uso das diversas substâncias. A maconha é normalmente utilizada de forma recreativa, devido aos sintomas causados, como sonolência e relaxamento. Já a cocaína, pode ser utilizada tanto para fins laborais, causa euforia e inibe a sonolência, como também para fins recreativos, em associação ao álcool. A anfetamina, por outro lado é uma substância bastante difundida no grupo dos motoristas de caminhão, não sendo considerada, por esses profissionais, uma droga como as demais.

Janela de detecção é definida como o tempo de deteç̧ão de uma substância em uma matriz biológica após sua administração. No fluido oral esse período é bastante semelhante ao sangue, podendo indicar a concentração real da substância no organismo no momento da coleta ${ }^{38}$. Os resultados encontrados em nosso trabalho apontaram para uma frequência mais baixa do uso de drogas quando comparado a outros estudos realizados no Brasil. Estudos de Leyton et al., $2012^{13}$ e Sinagawa et al., $2015^{102}$, relataram uma positividade de $9,3 \%$ e 5,4\% respectivamente. Ambos os estudos envolveram motoristas de caminhão que trafegavam em rodovias do estado de São Paulo, entretanto, diferentemente do presente estudo, ambos realizaram coletas de urina e não fluido oral. Como a urina possui uma janela de detecção superior ao fluido oral era esperado encontrar uma maior frequência do uso de drogas entre esses profissionais.

Comparando nossos resultados com outros estudos brasileiros que também realizaram coleta de fluido oral ${ }^{39,40}$ podemos observar um aumento da frequência encontrada de amostras positivas. Em estudo de 2013 foi relatado uma frequência de $3,1 \%$ de substâncias psicoativas em amostras de fluido oral de motoristas de caminhão, sendo que a substância ilícita mais encontrada foi a anfetamina ${ }^{40}$. 
Como já relatado na literatura ${ }^{103}$, nossos resultados apresentaram ainda, uma frequência de uso relativamente alta para as anfetaminas, considerando o controle legal sobre os medicamentos que possuíam como princípio ativo substâncias estimulantes. Diferente de países europeus ${ }^{104}$, no Brasil é mais frequente o uso de cocaína pela população, incluindo os motoristas de caminhão. Fato que poderia ser explicado pelo maior tráfico desse tipo de substância, levando em consideração a proximidade com países produtores da droga.

O uso de substâncias psicoativas por motoristas é frequente em vários países $46,47,105,106$, entretanto o Brasil apresenta hoje uma taxa de mortalidade por AT correspondente a países com baixo desenvolvimento. Muito ainda precisa ser feito para promover uma diminuição significativa do número de mortes no trânsito. Com o presente estudo obtivemos importantes dados sobre o uso de substâncias psicoativas por motoristas de caminhão e sobre o perfil desses motoristas. Dados esses que poderão ser utilizados por autoridades para implementação de políticas públicas visando melhorar a atual situação do trânsito brasileiro. 
CONCLUSÕES 


\section{Conclusões}

De acordo com os resultados obtidos neste trabalho pode-se concluir que:

- Ainda é frequente o uso de drogas ilícitas estudadas por motoristas de caminhão que trafegam nas estradas do estado de São Paulo;

- Cocaína é a droga mais consumida por motoristas profissionais;

- A probabilidade de envolvimento prévio em acidentes de trânsito é inversamente proporcional à escolaridade dos motoristas de caminhão e diretamente proporcional à distância percorrida e à jornada de trabalho;

- Os motoristas de caminhão com um maior percurso a ser viajado consomem mais anfetamina em comparação às demais substâncias;

- Os métodos de SPME para a detecção de cocaína, anfetamina e $\triangle 9-T H C$ em fluido oral apresentaram-se dentro das normas preconizadas internacionalmente. 
REFERÊNCLAS 


\section{Referências}

1. World Health Organization. Global status report on road safety. Supporting a Decade of Action. Geneva, Switzerland: World Health Organization,2015. http://www.who.int/violence_injury_prevention/roa d_safety_status/2013/en/ (Acesso em 21 de novembro de 2015).

2. DATASUS (Banco de Dados do Sistema Único de Saúde). Informações de Saúde - Epidemiológica e Morbidade, Ministério da Saúde. 2015

3. Vindenes $\mathrm{V}$, Jordbru $\mathrm{D}$, et al. Impairment based legislative limits for driving under the influence of non-alcohol drugs in Norway. Forensic Sci Int 2012 jun; 219: 1-11.

4. Gjerde H, Christophersen AS, Normann PT, Pettersen BS, Sabaredzovic A, Samuelsen SO. Analysis of Alcohol and Drugs in Oral Fluid From Truck Drivers in Norway Analysis of Alcohol and Drugs in Oral Fluid From Truck Drivers in Norway. Traffic Inj Prev 2011; 13: 438.

5. Instituto de Pesquisa Econômica e Aplicada - IPEA; Polícia Rodoviária Federal - PRF. Acidentes de trânsito nas rodovias federais brasileiras. Caracterização, tendências e custos para a sociedade. Brasil, 2015.

6. GEIPOT (Grupo Executivo de Integração da Política de Transportes). [Anuário Estatístico dos Transportes], Ministério dos Transportes. 2001.

7. Confederação Nacional do Transporte - CNT. Pesquisa CNT de redovias 2014. Brasil: CNT, 2015

8. Departamento Nacional de Infra-estrutura de Transportes - DNIT. Malha rodoviáia federal, 2015. Disponível em: http://www.dnit.gov.br/sistema-nacional-de-viacao/snv-2014-1\# (Acesso em 10/12/2015).

9. Ministério das Cidades, Departamento Nacional de Trânsito DENATRAN. Frota nacional de veículos, 2015. Disponível em: http://www.denatran.gov.br/frota2015.htm (Acesso em 10/12/2015).

10. Boletim Estatístico CNT 2009. Brasília (DF): Confederação Nacional do Transporte; 2009. [citado 2010 jan]. Disponível em: http://www.cnt.org.br/Imagens\%20CNT/PDFs\%20CNT/Boletim\%20Es tat\%C3\%ADstico/BoletimEstatistico.2009.pdf (Acesso em 10/12/2015). 
11. Williamson A, Friswell R. The effect of external non-driving factors, payment type and waiting and queuing on fatigue in long distance trucking. Accid Anal Prev 2013 set; 58:26-34.

12. Arnold PK, Hartley LR, Corry A, Hochstadt D, Penna F, Feyer AM. hours of work, and perceptions of fatigue among truck drivers. Accid. Anal Prev 1997 jul; 29(4):471-7.

13. Leyton V, Sinagawa DM, Oliveira KCBG, Schmitz W, Andreuccetti G, Martinis BS De, et al. Amphetamine, cocaine and cannabinoids use among truck drivers on the roads in the State of Sao Paulo, Brazil. Forensic Sci Int 2012 fev; 215(1-3):25-7.

14. da Silva-Junior FP, de Pinho RS, de Melo MT, de Bruin VM, de Bruin PF. Risk factor for depression on truck drivers. Soc Psychiatry Psychiatr Epidemiol 2009; 44 (2): 125-9.

15. Shen S, Li Y, Zhou M, Zhang C, Jiang Y, Kang Y. Depression status and associated factors in Chinese occupational truck drivers. Cell Biochem Biophys 2013; 67 (3): 1497-500.

16. Bogunz MJ, Smith RM. Forensic Science. $2^{a}$ ed, v 6. Elsevier, 2008.

17.Passagli MF. Toxicologia Forense: Teoria e Prática. Campinas: Millennium. 2013.

18. Oga S, Camargo MMA, Batistuzzo JAO. Fundamentos de Toxicologia. $3^{\underline{a}}$ ed. São Paulo: Atheneu, 2008

19. CEBRID (Centro Brasileiro de Informações sobre Drogas Psicotrópicas - EPM). Jogo de folhetos explicativos sobre drogas psicotrópicas, 2003. 2003.

20. Yonamine M. A saliva como espécime biológico para monitorar o uso de álcool, anfetamina, metanfetamina, cocaína e maconha por motoristas profissionais [tese]. São Paulo: Faculdade de Ciências Farmacêuticas, Universidade de São Paulo; 2004.

21. European Monitoring Centre for Drugs and Drug Addiction. Relátorio europeu sobre drogas: tendências e evoluções. 2015

22. Transportation Research Board. Drugs and Alcohol Committee - Drugs and traffic: A Symposium. Transportation Research Circular. 2006.

23. Kranzler HR, Korsmeyer P. Encyclopedia of drugs, alcohol and addictive behavior. Grale, Cengage. 2009.

24. European Monitoring Centre for Drugs and Drug Addiction. Drug use, impaired driving and traffic accidents. EMCDDA. 2015. 
25. BRASIL. Ministério da Saúde. Agência Nacional de Vigilância Sanitária. Legislação - RDC ํㅜ 50, 25 de setembro de 2014.

26. Logan BK, Fligner CL, Haddix T. Cause and manner of death in fatalities involving methamphetamine. J. Forensic Sci. 1998;43:28-34.

27. Portal Transporta Brasil. Rebite em motoristas profissionais [Internet]. 2012.Disponível em: http://www.transportabrasil.com.br/2012/08/rebite-em-motoristasprofissionais/ (Acesso em: 08/11/2015)

28. Couper FJ, Logan BK. Drugs and Human Performance Fact Sheets. National Highway Traffic Safety Administration - U.S. Department of Transportation, 2014.

29. Jones AW In B Madea (Ed.). Effects of alcohol on fitness to drive. Handbook of forensic medicine. 2014 p. 1057-1073.

30. Stoduto G, Mann RE, Lalomiteanu A, Wickens CM, Brands B. Examining the link between collision involvement and cocaine use. Drug Alcohol Depend 2012 jun; 123(1-3):260-3

31. Drummer OH, Gerostamoulos D, Chu M, Swann P, Boorman M, Cairns I. Drugs in oral fluid in randomly selected drivers. Forensic Sci Int 2007 ago;170(2-3):105-10.

32. World Health Organization. Drug Use and Road Safety: a policy brief Geneva, Switzerland, 2016.

33. Elvik R. Risk of road accident associated with the use of drugs: A systematic review and meta-analysis of evidence from epidemiological studies. Accid Anal Prev 2013; 60: 254-67.

34. Gates J, Dubois S, Mullen N, Weaver B, Bédard M. The influence of stimulants on truck driver crash responsibility in fatal crashes. Forensic Sci Int. 2013;228:15-20.

35. Chipman ML, Macdonald S, Mann RE. Being "at fault" in traffic crashes: does alcohol, cannabis, cocaine, or polydrug abuse make a difference?. Inj Prev 2003; 9 (4): 343-8.

36. Drummer OH, Kourtis I, Beyer J, Tayler P, Boorman M, Gerostamoulos D. The prevalence of drug in injured drivers. Forsensic Sci Int 2012; 215: 14-17.

37. Bogstrand ST, Gjerde H, Normann PT, Rossow I, Ekeber O. Alcohol psychoactive substances and non-fatal road traffic accidents - a casecontrol study. BMC Public Health 2012; 3: 734

38. Jones AW, Holmgren A, Ahlner J. High prevalence of previous arrest for illicit drug use and/or impaired driving among drivers killed in motor 
vehicle crashes in Sweden with amphetamine in blood at autopsy. Int J Drug Policy. 2015; 26 (8): 790-3.

39. Secretaria Nacional Antidrogas - SENAD. Uso de bebidas alcoólicas e outras drogas nas rodovias brasileiras e outros estudos. Porto Alegre: SENAD; 2010.

40. Yonamine M, Sanches LR, Aparecida B, Bismara P, Almeida RM De, Andreuccetti G, et al. Detecting Alcohol and Illicit Drugs in Oral Fluid Samples Collected from Truck Drivers in the State of São Paulo, Brazil. Traffic Injury Prevention. 2013;14(2):127-31.

41. Moffat AC, Osselton MD, Widdop B. Clarke's analysis of drugs and poisoning. $4^{\text {th }}$ ed. Pharmaceutical Press. 2011.

42. Drummer OH. Drug Testing in Oral Fluid. Clin Biochem Rev 2006 ago; 27(3):147-59.

43. Gjerde H, Øiestad EL, Christophersen AS. Using biological samples in epidemiological research on drugs of abuse. Norsk Epidemiologi 2011;21(1):5-14.

44. Cone EJ, Huestis MA. Interpretation of Oral Fluid Tests for Drugs of Abuse. Ann N Y Acad Sci 2007 mar; 1098:51-103

45. Edvardsen HME, Moan IS, Christophersen AS, Gjerde $H$. Use of alcohol and drugs by employees in selected business areas in Norway: a study using oral fluid testing and questionnaires. J Occup Med Toxicol. 2015; 16: 10:46.

46. Federal Highway Research Institute. About DRUID: Driving under the Influence of Drugs, Alcohol and Medicines. 2014. Disponível em: http://www.druid-project.eu/Druid/EN/Home/home_node.html. (Acesso em: 28/01/2016).

47. National Highway Traffic Safety Administration. 2007 National Roadside Survey of Alcohol and Drug Use by Drivers - Methodology. NHTSA. 2007 p. 196.

48. MacCall C, Ritchie G, Sood M. Oral fluid testing as an alternative to urine testing for drugs of abuse in inpatient forensic settings: giving patients choice. Scottish Medical Journal. 2013;58(2):99-103.

49. Kunkel F, Fey E, Borg D, Stripp R, Getto C. Assesment of the use of oral fluid as matrix for drug monitoring in patients undergoing treatment for oppioid addiction. J. Opioid Manag 2015; 11 (5): 435-42.

50. Wong RC, Tran M, Tung JK. Oral fluid drug tests : Effects of adulterants and foodstuffs. Forensic Science International. 2005;150:175-80 
51. Kelley-Baker T, Moore C, JH Lacey, Yao J. Comparing drug detction in oral fluid and blood: data from a national sample of nightimes drivers. Traffic Inj Prev 2014 15(2); 111-118.

52. Verstraete AG. Detection Times of Drugs of Abuse in Blood, Urine, and Oral Fluid. Ther Drug Monit. 2004 abr;26(2):200-5.

53. Siegel JA, Saukko PJ. Encyclopedia of Forensic Sciences. Second Edition, Elsevier, 2013.

54. Silva OA, Greve JMD, Yonamine M, Leyton V. Drug use by truck drivers in Brazil. Drugs: Educ., Prev. Policy 2003;10(2):135-9.

55. Moore C, Kelley-baker T, Lacey J. Field Testing of the Alere DDS2 Mobile Test System for Drugs in Oral Fluid. J Anal Toxicol 2013 jun;37(5): 305-7.

56. European Workplace Drug Testing Society (EWDTS). European Laboratory Guidelines for Legally Defensible Workplace Drug Testing, 2002.

57. BRASIL, LEI № 9.503, DE 23 DE SETEMBRO DE 1997 Código de Trânsito Brasileiro - CTB. Disponível em: http://www.planalto.gov.br/ccivil_03/leis/L9503Compilado.htm (Acesso em: 23/08/2016).

58. Christophersen AS, Morland J, Stewart K, Gjerde H.International Trends in Alcohol and Drug Use Among Vehicle Drivers. Forensic Sci Rev 2016; 28: 37-66.

59. Driving or being in charge of a motor vehicle with concentration of specified controlled drug above specified limit. Update (2013) to section 5A of United Kingdom Road Traffic Act 1988 Disponível em: http://www.legislation.gov.uk/ukpga/2013/22/section/56/prospective\#s ection-56-1. (Acesso em: 6/04/2016).

60. Van der Linden T, Legrand SA, Silverans P, Verstraete AG. DUID: oral fluid and blood confirmation compared in Belgium. J Anal Toxicol 2013; 36(6): 418-21.

61. Ley Orgánica $5 / 2010$, de 22 de junio, por la que se modifica la Ley Orgánica 10/1995, de 23 de noviembre, del Código Penal [Institutional Act 5/2010 (22 June) amending Criminal Code Institutional Act 10/1995 (23 November)].

62. Woolley JE, Baldock MRJ. Review of Western Australian Drug Driving Laws. Centre for Automotive Safety Research, 2009.

63. Pehrson A, Blencowe T, Vimpari K, Langel K, Engblom C, Lillsunde P. An Evalutaion Of On-Site Oral Fluid Screening Devices Drugwipe 5+ 
And Rapidstat Using Oral Fluid for Confirmation Analysis. J Anal Toxicol 2011; 35: 211-8.

64.EU Project ROSITA 2. Evaluation of Different Roadsite Drug Tests. http://rosita.org/ (Acesso em 31/08/2016).

65. Musshof F, Hokamp EG, Bott U, Madea B. Performance evaluation of on-site oral fluid drug screening devices in normal police procedure in Germany. Forensic Sci Int 2014; 238: 120-4

66. Ellefsen KN, Concheiro M, Pirard S, Gorelick DA, Huestis MA. Cocaine and Benzoylecgonine oral fluid on-site screening and confirmation. Drug Test Anal 2016; 8: 296-303.

67. Stano-Rossi S, Castrignanò E, Anzillotti L, Serpelloni G, Mollica R, Tagliaro F, Pascali JP, di Stefano Delfina, Sgalla R, Chiarotti M. Evaluation of four oral fluid devices (DDS, Drugtest 5000, Drugwipe 5+ and RapidSTAT) for on-site monitoring drugged driving in comparison with UHPLC-MS/MS analysis. Forensic Sci Int 2012; 221: 70-6.

68. Moreau RLM, Siqueira MEPB. Toxicologia Analítica. $2^{\underline{a}}$ ed. Rio de Janeiro: Guanabara Koogan, 2016.

69. Kataoka H, Saito K. Recent advances in SPME techmiques in biomedical analysis. J Pharm Biomed Anal, 2011; 54: 926-50.

70.Spietelun A, Marcinkowski L, de la Guardia M, Namiesnik J. Recent developments and future trends in solid phase microextraction techniques towards green analytical chemistry. J Chromatogr A 2013; 1321: $1-13$

71. Arthur CL, Pawliszyn J. Solid phase microextraction with thermal desorption using fused silica optical fibers. Anal Chem, 1990; 62: 214548.

72. Pragst F. Application of solid-phase microextraction in analytical toxicology. Anal Bioanal Chem 2007; 388: 1393-1414.

73. Lord $\mathrm{H}$, Pawliszyn J. Microextrzction of drugs. Journal of Chromatography. 2000; 902: 17-63.

74. Gorynski K, Gorynska P, Gorska A, Harezlak T, Jaroch A, Jaroch K, Lendor S, Skobowiat C, Bojko B. SPME as a promising tool in translational medicine and drug discovery: From bench to bedside. $J$ Pharm Biomed Anal 2016; 9.

75. Yonamine M, Tawil N, Moreau RL, Silva OA. Solid-phase microextraction-gas-chromatography-mass spectrometry and headspacegas chromatography of tetrahydrocannabinol, amphetamine, methamphetamine, cocaine ande ethanol in saliva samples. 2003 Jun $5 ; 789(1): 73-8$. 
76. Lund HM, Oiestad EL, Gjerde H, Christophersen AS. Drugs of abuse in oral fluid collected by two different sample kits - Stability testing and validation using ultra performance tandem mass spectrometry analysis. J Chromatogr B Analyt Biomed Life Sci 2011; 879: 3367-77.

77. Scientific Working Group for Forensic Toxicology. Standard Practices for Method Validation in Forensic Toxicology. SWGTOX; 2013.

78. United Nations Office on Drugs and Crime. Guidance for the Validation of Analytical Methodology and Calibration of Equipment used for Testing of Illicit Drugs in Seized Materials and Biological Specimens: A commitment to quality and continuous improvement. Vienna:UNODC;2009.

79. Peters FT, Drummer $\mathrm{OH}$, Musshoff F. Validation of new methods. Forensic Sci Int. 2007; 165: 216-224.

80. Armbruster DA, Pry T. Limit of blanck, limit of detection and limit of quantitation. Clin Biochem Rev 2008; 29: 49-52.

81. Almeida AM, Castel-Branco MM, Falcão AC. Linear regression for calibration lines revisited: weighting schemes for bioanalytical methods. J Chromatogr B Analyt Technol Biomed Life Sci. 2002; 774 (2): 215-222.

82. Silva MMA, Morais Neto OL, Lima CM, M DC, Silva Jr. JB. Projeto Vida no Trânsito - 2010 a 2012: uma contribuição para a Década de Ações para a Segurança no Trânsito 2011-2020 no Brasil. Epidemiol. Serv. Saúde 2013; 22(3): 531-536.

83. Segunda Conferência Global de Alto Nível sobre Segurança no Trânsito: Tempo de Resultados. Declaração de Brasília. Nov 2015.

84.Sinagawa DM. Uso de substâncias psicoativas por motoristas profissionais no Estado de São Paulo [dissertação]. São Paulo: Faculdade de Medicina, Universidade de São Paulo; 2015.

85. Pelição FS, Peres MD, Pissinate JF, et al. Predominance of alcohol and illicit drugs among traffic accidents fatalities in an urban area of Brazil. Traffic Inj Prev. 2016; 18.

86. Langel K, Engblom C, Pehrsson A, Gunner T, Ariniemi K, Lillsunde P. Drug testing in oral fluid-evaluation of sample collection devices. J Anal Toxicol 2008; 32 (6): 393-401.

87. Wille SM, Baumgartner MR, Fazio VD, Samyn N Kraemer T. Trends in drug testing in oral fluid and hair as alternative matrices. Bioanalysis 2014; 6 (17); 2193-209. 
88. Quintela O, Crouch DJ, Andrenyak DM. Recovery of drugs of abuse from the Immunalisys Quantisal oral fluid collection device. J Anal Toxicol 2006; 30 (8): 614-16.

89. Kirschbaum KM, Musshoff F, Wilbert A, Röhrich J, Madea B. Direct ELISA kit as a sensiteve and selective screening method for abstinence control in urine. Forensic Sci Int 2011; 207 (1-3): 66-9.

90. Montesano C, Simeoni MC, Curini R, Sergi M, Lo Sterzo C, Compagnone D. Determination of illicit drug and metabolites in oral fluid by microextraction on packed sorbent coupled with LC-MS/MS. Anal Bioanal Chem. 2015; 407 (13): 3647-58.

91.Souza DZ, Boehl PO, Comiran E, Zancanaro I, Fuentefria AM, Pechansky $\mathrm{F}$, et al. Which Amphetamine-Type Stimulants Can Be Detected by Oral Fluid Immunoassays? Ther Drug Monit. 2011;34(1):98-109.

92. Comiran E, Souza DZ, Boehl PO, Mariotti KDC, Pechansky F, Arruda $\mathrm{C}$, et al. Fenproporex and Amphetamine Pharmacokinetics in Oral Fluid After Controlled Oral Administration of Fenproporex. Ther Drug Monit. 2012;34(5):545-53.

93. Ocaña-González JA, Fernandez-Torres R, Bello-Lopes MA, RamosPayán M. New developments in microextraction techniques in bioanalysis. A review. Analytica Chimica Acta. 2016; 905: 8-23.

94.Dassanayake T, Michie P, Carter G, Jones A. Effects of Benzodiazepines, Antidepressants and Opioids on driving: a systematic review and meta-analysis of epidemiological and experimental evidence. Drug Safety. 2011; 34 (2): 125-56.

95. Hetland A, Carr DB. Medicantions and Impaired Driving: A Review of the Literature. Ann Pharmacother. 2014; 48(4): 494-506.

96. Stone BT, Correa KA, Brown TL et al. Behavioral and Neurophisiological signatures of Benzidiazepines-Related Driving Impairments. Frontiers in Psychology. 2015; 26: 1799.

97.Romano E, Pollini RA. Patterns of Drug Use in Fatal Crashes. Addiction. 2013; 108 (8): 1428-1438.

98. Bramness JG, Skurtveit S, Morland J. Imparment due to intake of carisoprodol. Drug and Alcohol Dependence. 2004; 74: 311-18.

99. European Medicines Agency - EMA. Perguntas e Respostas relativas à suspensão da Autorização de Introdução no Mercado para os medicamentos contrndo meprobamato para uso oral. Science Medicine Health. 2012 
100. Robertson MD, Martinetti LJ. Carisoprodol - Effects on Human Performance and Behaviror. Forensic Sci Rev. 2003; 15: 1-9.

101. Bramness JG, Skurtveit S, Morland J, Engeland A. The risk of traffic accidents after prescriptions of carisoprodol. Accident Analysis and Prevention. 2007; 39: 1050-55.

102. Sinagawa DM, de Carvalho HB, Andreucetti G et al. Association between travel lenght and drug use among brazilian truck drivers. Traffic Injury Prevention. 2015; 16: 5-9.

103. Oliveira LG, Endo LG, Sinagawa DM, Yonamine M, Muñoz DR, Leyton V. A continuidade do uso de anfetaminas por motoristas de caminhão no Estado de São Paulo, Brasil, a despeito da proibição de sua produção, prescrição e uso. Cad Saúde Pública. 2013;29(9):19039.

104. Bramness JG, Reid MJ, Solvik KF, Vindenes V. Recent trends in the availability and use of amphetamine and methamphetamine in Norway. Forensic Sci Int. 2015; 246: 92-7.

105. Senna MC, Augsburger M, Aebi B, Briellman TA, Donzé N, Dubugnon, JL, Iten PX, Staub C, Sturm W, Sutter K. First nationwide study on driving under the influence of drugs in Switzerland. Forensic Sci Int, 2010; 198: 11-16.

106. Fierro I, Gonzaléz-Luque JC, Segui-Goméz M, Álvarez FJ. Alcohol and drug use by Spanish drivers:Comparison of two cross-sectional road-side surveys (2008-9/2013). Int J Drug Policy, 2015; 26: 794-7. 


\section{Anexo A (frente)}

Faculdade de Medicina da Universidade de São Paulo

Departamento de Medicina Legal, Ética Médica e Medicina Social e do

Trabalho

TERMO DE CONSENTIMENTO LIVRE E ESCLARECIDO

\section{I - DADOS DE IDENTIFICAÇÃO DO SUJEITO DA PESQUISA}

Nome:

Documento de Identidade: Sexo: ( ) M ( )F

Data de nascimento:

Endereço:

$\mathrm{N}^{0}$.

Apt:

Bairro:

Cidade:

CEP:

Telefone:

$$
\text { II - DADOS SOBRE A PESQUISA CIENTÍFICA }
$$

1. TÍTULO DO PROTOCOLO DE PESQUISA:

Uso de substâncias psicoativas por motoristas profissionais

PESQUISADORA: Profa. Dra. Vilma Leyton

CARGO/FUNÇÃO: Professora Doutora

INSCRIÇÃO NO CONSELHO REGIONAL N 6.108

UNIDADE DO HCFMUSP: Departamento de Medicina Legal, Ética Médica e Medicina Social e do Trabalho

\section{AVALIAÇÃO DO RISCO DA PESQUISA}

$\begin{array}{lll}\text { Sem Risco ( ) } & \text { Risco Minimo ( } x) & \text { Risco Médio ( ) } \\ \text { Risco Baixo ( ) } & \text { Risco Alto ( ) } & \\ \text { 3. DURAÇÃO DA PESQUISA: 12 meses } & \end{array}$

\section{III - REGISTRO DAS EXPLICAÇŌES DO PESQUISADOR AO SUJEITO DA PESQUISA SOBRE A PESQUISA}

1. Justificativa e os objetivos da pesquisa; 2 . procedimentos que serão utilizados e propósitos, incluindo a identificação dos procedimentos; 3 . desconfortos e riscos esperados; 4 . benefícios que poderão ser obtidos.

1. Esta pesquisa está sendo feita para avaliar o quanto os motoristas profissionais têm utilizado substância psicoativas, principalmente os "rebites", e 
Anexo A (verso)

explicar os riscos que essas substâncias podem acometer ao motorista e à sociedade como um todo.

2. O senhor (a) deverá responder a um questionário.

3. Será coletada uma amostra de urina e uma amostra de fluido oral.

4. O senhor (a) não será identificado (a).

5. Estamos coletando apenas informações sobre sua profissão e saúde (dados obtidos do questionário)

6. Mesmo que seu exame toxicológico seja positivo, o senhor (a) não será identificado (a) de forma nenhuma.

7. Não há desconfortos para a coleta das amostras biológicas e os riscos dessa pesquisa são mínimos.

8. Os benefícios deste tipo de pesquisa é ajudar a implantar políticas para um trânsito mais seguro.

\section{ESCLARECIMENTOS DADOS PELO PESQUISADOR SOBRE GARANTIAS DO SUJEITO DA PESQUISA CONSIGNANDO:}

1. Acesso, a qualquer tempo, às informações sobre os procedimentos, riscos e benefícios relacionados à pesquisa, inclusive para dirimir eventuais dúvidas. O principal pesquisador é a Profa Dra. Vilma Leyton, que pode ser encontrado no endereço: Av. Dr. Arnaldo, 455 - Cerqueira César, São Paulo SP, tel: (11) 3061-8414. Se você tiver alguma consideração ou dúvida sobre a ética da pesquisa, entre em contato com o Comitê de Ética em Pesquisa (CEP) - Rua Ovídio Pires de Campos, 255 - $5^{\circ}$ andar - tel: (11) 3069-6442, ramais 16,17,18 ou 20, FAX: 3069-6442 ramal 26 - E-mail: cappesq@hcnet.usp.

2. Liberdade de retirar o seu consentimento a qualquer momento e de deixar de participar do estudo.

3. Salvaguarda da confidencialidade, sigilo e privacidade.

\section{CONSENTIMENTO PÓS-ESCLARECIDO}

Declaro que, após convenientemente esclarecido pelo pesquisador e ter entendido o que me foi explicado, consinto em participar do presente Protocolo de Pesquisa.

de de 20 


\section{Anexo B}

\section{PLANIUEA DE COLETA DE DADOS}

Número de Controle Laboratorial: Entrevistador:

Participante: ( ) Aceitou participar ( ) Recusou participar, motivo:

Idade: Sexo: Feminino ( ) Masculino ( )

Naturalidade (Cidade/UF):

Estado civill: Solteiro ( ) Casado ( ) Viúvo ( ) Divorciado ( ). Amasiado ( ) Etmia: Branca ( ) Negro ( ) Amarelo ( ) Pardo ( )

Escolaridade: Nunca estudou ( ) $2^{\circ}$ grau () Outro:

$\begin{array}{lll}1^{\circ} \text { a } 4^{\circ} \text { série } & \left(\text { ) } \quad 2^{\circ} \text { Grau Incompleto ( ) }\right. \\ 5^{\circ} \text { a } 8^{\circ} \text { série } & (\text { ) } & \text { Superior }\end{array}$

$5^{\circ}$ a $8^{\circ}$ série

( ) Superior

Curso técnico

Tempo de Profissão:

( ) anos

Superior Incompleto ( )

Servico: Contratado ( ) Autônomo ( ) Aposentado ( )

Percurso (Cidade/UH) Distáncia: _ $\mathrm{km} /$ Horas totais da viagem:

Origem:

Destino:

Tempo de descanso: _ h/ noite h

Já se envolveu emi AT? Sim () Não (

Horas viajadas (até agorạ):

Quantos?

Dirige direto quantas horas h

Nos filtim

Média de horas dirigidas por dia (24h):

$N^{\circ}$ de ocuparates, no veículo:

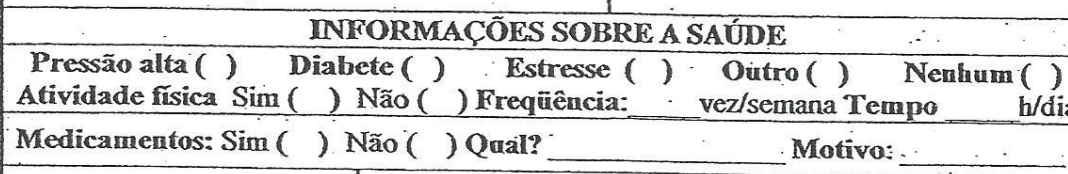

Sim ( ) Não( ) Úlima vez?

Faz uso de bebidas $\quad$ Frequêeucia nos últimos 12 meses (vezes por semana) alcoólicas?
( ) diariamente
( ) 1 vez por semana

( ) 2-3 vezes por semana

( ) 4-5 vezes por semana

Tipo de bebida: Cerveja ( ) Destilados ( ) Vinho ( ) Outros:

\begin{tabular}{|c|c|}
\hline Fum & $\begin{array}{l}\text { Sim ( ) Ex-fumante ( ) Não ( ) } \\
\text { Tempo de uso: } \\
\text { Quantidade de cigarros por dia: }\end{array}$ \\
\hline 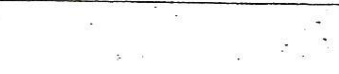 & $\begin{array}{l}\text { Sim ( ) Já usei ( ) Não ( ) } \\
\text { Qual? }\end{array}$ \\
\hline Usa rebite? & $\begin{array}{l}\text { Freqüência (vezes por semana): } \\
\begin{array}{ll}\text { () diariamente } & \text { (.) 1 vez por semana } \\
\text { () } 2-3 \text { vezes por semana } & \text { ( ) } 4-5 \text { vezes por semana } \\
\text { Quando foi a última vez? } & \end{array}\end{array}$ \\
\hline$\therefore \quad \therefore$ & $\begin{array}{l}\text { Onde adquiriu? } \\
\text { () Posto de gasolina ( ) Amigos ( ) Outros } \\
\text { Motivo para uso? } \\
\text { ( ) Manter acordado ( ) Outro motivo }\end{array}$ \\
\hline $\begin{array}{l}\text { Usa outro tipo de droga? } \\
\text { Maconha ( ) Crack ( ) } \\
\text { Cocaina ( ) Outras ( ) }\end{array}$ & $\begin{array}{l}\text { Uso ( ) Nunca ( ) Já usei () } \\
\text { Fréüência (vezes por semana): } \\
\begin{array}{ll}\text { ( ) diariamente } & \text { (") i vez por semana } \\
\text { ( ) 2-3 veczes por semana } & \text { ( ) 4-5 vezes por semana } \\
\text { Quamdo foi a ulltima vez? } & \end{array}\end{array}$ \\
\hline
\end{tabular}

Outras informações relevantes: 
Anexo C

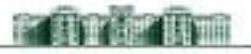 \\ MEDICINA \\ TSP \\ COMITÊ DE ÉTICA EM PESQUISA
}

\begin{abstract}
APROVAÇÃo
O Comitê de Ética em Pesquisa da Faculdade de Medicina da Universidade de São Paulo, em sessão de 04/o6/2014, APROVOU o Protocolo de Pesquisa no 135/14 intitulado: "ANÁLISE DE ANFETAMINA, COCAÍNA E CANNABIS EM FLUIDO ORAL DE MOTORISTAS DE CAMINHÃO QUE TRAFEGAM EM RODOVIAS DO ESTADO DE SÃo PAULO" apresentado pelo Departamento de Medicina Legal, Ética Médica e Medicina Social e do Trabalho

Cabe ao pesquisador elaborar e apresentar ao CEPFMUSP, os relatórios parciais e final sobre a pesquisa (Resolução do Conselho Nacional de Saúde nº 466/12).

Pesquisador (a) Responsável: Vilma Leyton

Pesquisador (a) Executante: Henrique Silva Bombana
\end{abstract}

CEP-FMUSP, og de Junho de 2014.

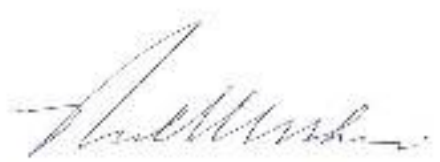

Prof. Dr. Paulo Eurípedes Marchiori Vice-Coordenador Comitê de Ética em Pesquisa 